\title{
Immunomodulatory Effects of Edible and Medicinal Mushrooms and Their Bioactive Immunoregulatory Products
}

\author{
Shuang Zhao ${ }^{1}$, Qi Gao ${ }^{1}$, Chengbo Rong ${ }^{1}$, Shouxian Wang ${ }^{1}$, Zhekun Zhao ${ }^{1,2}$, Yu Liu ${ }^{1}$ and \\ Jianping $\mathrm{Xu}^{3, * \mathbb{D}}$ \\ 1 Institute of Plant and Environment Protection, Beijing Academy of Agriculture and Forestry Sciences, \\ Beijing 100097, China; zhaoshuang@ipepbaafs.cn (S.Z.); gaoqi@ipepbaafs.cn (Q.G.); \\ rongchengbo@ipepbaafs.cn (C.R.); wangshouxian@ipepbaafs.cn (S.W.); zhaozhekun@ipepbaafs.cn (Z.Z.); \\ liuyu@ipepbaafs.cn (Y.L.) \\ 2 College of Life Sciences and Food Engineering, Hebei University of Engineering, Handan 056038, China \\ 3 Department of Biology, McMaster University, Hamilton, ON L8S 4K1, Canada \\ * Correspondence: jpxu@mcmaster.ca
}

Received: 10 October 2020; Accepted: 2 November 2020; Published: 8 November 2020

\begin{abstract}
Mushrooms have been valued as food and health supplements by humans for centuries. They are rich in dietary fiber, essential amino acids, minerals, and many bioactive compounds, especially those related to human immune system functions. Mushrooms contain diverse immunoregulatory compounds such as terpenes and terpenoids, lectins, fungal immunomodulatory proteins (FIPs) and polysaccharides. The distributions of these compounds differ among mushroom species and their potent immune modulation activities vary depending on their core structures and fraction composition chemical modifications. Here we review the current status of clinical studies on immunomodulatory activities of mushrooms and mushroom products. The potential mechanisms for their activities both in vitro and in vivo were summarized. We describe the approaches that have been used in the development and application of bioactive compounds extracted from mushrooms. These developments have led to the commercialization of a large number of mushroom products. Finally, we discuss the problems in pharmacological applications of mushrooms and mushroom products and highlight a few areas that should be improved before immunomodulatory compounds from mushrooms can be widely used as therapeutic agents.
\end{abstract}

Keywords: bioactive compounds; FIP; human health; immunomodulation; induced apoptosis; lectin; medicinal mushrooms; polysaccharide; terpenes and terpenoids

\section{Introduction}

In clinical practice, immunomodulators are usually classified into three categories: immunosuppressants, immunostimulants, and immunoadjuvants [1]. Their market share has increased rapidly over the past few years due to wide-ranging medical applications for patients that require human immune system modulations. Immune system modulations are also commonly used as prophylactic medicine for an increasing number of healthy people [2,3]. While most immunomodulators are synthetic or semi-synthetic compounds, there has been a growing interest in natural immunomodulators. Many natural compounds have shown significant immunomodulatory and overall health-benefiting effects to humans, with no or minimal toxicity. These natural-based products with potential pharmacological and beneficial effects are increasingly perceived as safer than synthetic compounds by the general public [4,5]. Indeed, many of the currently used chemical drugs have negative side effects 
and the market share of natural immunomodulators is increasing rapidly with an annual growth rate of $8.6 \%[1,6]$.

Medicinal mushrooms (MMs) are an important source of natural immunomodulators. Representing a subset of all mushrooms, MMs are broadly defined as macroscopic fungi that are used in the form of extracts or whole mushroom powder for human health benefits [7]. The health benefits may come in the form of helping to prevent and/or treat diseases in humans, and to create a dietary balance of a healthy diet. Dating back to thousands of years, MMs have been historically used as herbal medicines for human health, such as for the treatment of infectious diseases, gastrointestinal disorders and asthmatic conditions [8]. The biomass or specific extracts from all developmental stages of MMs, including the fruiting body, sclerotium, mycelium, and spores, have been used as health foods or dietary supplements $[9,10]$. Some of the extracted nutrients from mushrooms known as mushroom nutraceuticals have been made into capsules or tablets as dietary supplements. Regular intake of these nutraceuticals has been associated with enhancement of the human immune response, leading to increased resistance to infectious diseases and faster recovery from a diversity of diseases [11].

At present, thousands of branded MM products are sold all over the world. The health benefits of MM products include anticancer, immune-stimulation, antioxidant, antihyperglycemic, antihypertensive, neuroprotective, hepatoprotective, antidiabetic, antifungal, antibacterial, and antiviral activities [7,12]. Their effects have been attributed to many components, such as minerals, essential amino acids, dietary fiber, proteins, polysaccharides, lipopolysaccharides, glycoproteins, and secondary metabolites. Among these, some of the complex organic compounds have shown immunomodulatory effects [7]. For example, polysaccharides from MMs can activate natural killer cells, macrophages, and neutrophils, as well as induce innate immune cytokines and interleukins. In addition, secondary metabolites from MMs, such as sterols, terpenes, and phenols can enhance the survival of hosts by stabilizing their important metabolic functions [8].

Different MMs contain different functional components that may impact the same or different immunomodulatory pathways at varying efficacies. In the following sections, we first provide a brief description of the known MMs. We then summarize the diversity, structure, function, and molecular mechanism of action of functional ingredients from MMs that have shown to be involved in immunomodulation. We finish by briefly describing how genomics can accelerate research on medicinal mushrooms.

\section{Medicinal Mushrooms}

As mentioned above, medicinal mushrooms refer to all macroscopic fungi whose extracts or powder form from any stages of the mushroom development have shown documented beneficial effects on health [13]. These beneficial effects may have been shown in the forms of in vitro, ex vivo, or in vivo activities. Their effects may cover different groups of organisms such as antagonistic effects against human pathogens and parasites, and/or beneficial effects for human and animal cell lines, or animal and human individuals [11]. Since many edible mushrooms and their products have shown to be a beneficial component of the human diet, some of these edible mushrooms are also commonly included as medicinal mushrooms [7]. In our literature search, a large number of MMs have been documented. For example, terpenes and terpenoids from Ganoderma lucidum could stimulate the expressions of genes coding for proteins in the nuclear factor (NF)-kB pathway and modulate immune system functions [14]. Heteroglycan and heteroglycan-peptide from the mushroom of Hericium erinaceus can modulate the immuno-effects by inducing nitric oxide production and increasing expression of tumor necrosis factor (TNF)- $\alpha$, interleukin (IL)-1 $\beta$, IL-12 [15]. These mushrooms belong to two fungal phyla, Ascomycota and Basidiomycota. Most of the MMs are in phylum Basidiomycota. Table 1 shows the major medicinal mushrooms, including their taxonomy and geographic/ecological distributions. As can be seen, some of these mushrooms are broadly distributed (e.g., the button mushroom Agaricus bisporus) while others are geographically more restricted (e.g., the Himalayan caterpillar fungus Ophiocordyceps sinensis). Some of the mushrooms included in the table e.g., Amanita phalloides are highly poisonous when 
consumed by humans. However, the dilutions of an A. phalloides extract that contains the toxin amanitin have shown to be effective as an anti-tumor therapy [16].

Table 1. Major medicinal mushrooms and their main distributions.

\begin{tabular}{|c|c|c|c|}
\hline MM Species & Common Name & Taxonomy & $\begin{array}{c}\text { Geographic/Ecological } \\
\text { Distribution }\end{array}$ \\
\hline Agrocybe aegerita & $\begin{array}{l}\text { Black Poplar } \\
\text { mushroom }\end{array}$ & $\begin{array}{c}\text { Basidiomycota } \\
\text { Agaricomycetes } \\
\text { Agaricales } \\
\text { Bolbitiaceae }\end{array}$ & $\begin{array}{l}\text { North temperate and } \\
\text { subtropical zone }\end{array}$ \\
\hline Agaricus bisporus & $\begin{array}{l}\text { Button mushroom, } \\
\text { Portobello mushroom, } \\
\text { Common mushroom }\end{array}$ & $\begin{array}{l}\text { Basidiomycota } \\
\text { Agaricomycetes } \\
\text { Agaricales } \\
\text { Agaricaceae }\end{array}$ & $\begin{array}{c}\text { USA, China, France, Netherlands, } \\
\text { United Kingdom, Italy, Poland, } \\
\text { Spain, Germany, Canada, Ireland, } \\
\text { Belgium, Indonesia, Hungary and } \\
\text { Mexico }\end{array}$ \\
\hline $\begin{array}{l}\text { Agaricus blazei } \\
\text { (syn. Agaricus } \\
\text { brasiliensis) }\end{array}$ & $\begin{array}{l}\text { Royal Sun Agaricus, } \\
\text { Almond Portobello }\end{array}$ & $\begin{array}{c}\text { Basidiomycota } \\
\text { Agaricomycetes } \\
\text { Agaricales } \\
\text { Agaricaceae }\end{array}$ & America, Brasil, Japan, China \\
\hline Amanita phalloides & Death Cap & $\begin{array}{l}\text { Basidiomycota } \\
\text { Agaricomycetes } \\
\text { Agaricales } \\
\text { Amanitaceae }\end{array}$ & Europe, North American, Asia \\
\hline Boletus edulis & $\begin{array}{l}\text { Cep, Porcini, Penny } \\
\text { Bun Bolete }\end{array}$ & $\begin{array}{l}\text { Basidiomycota } \\
\text { Agaricomycetes } \\
\text { Boletales } \\
\text { Boletaceae }\end{array}$ & $\begin{array}{l}\text { China, Italy, France, Swiss, } \\
\text { Germany }\end{array}$ \\
\hline Boletus speciosus & $\begin{array}{l}\text { Red-Capped Butter } \\
\text { Bolete }\end{array}$ & $\begin{array}{c}\text { Basidiomycota } \\
\text { Agaricomycetes } \\
\text { Boletales } \\
\text { Boletaceae }\end{array}$ & $\begin{array}{c}\text { Eastern North America, } \\
\text { Southwest of China and Europe }\end{array}$ \\
\hline Chroogomphus rutilus & Copper Spike & $\begin{array}{c}\text { Basidiomycota } \\
\text { Agaricomycetes } \\
\text { Boletales } \\
\text { Gomphidiaceae }\end{array}$ & China \\
\hline Clitocybe nebularis & Clouded Funnel & $\begin{array}{c}\text { Basidiomycota } \\
\text { Agaricomycetes } \\
\text { Agaricales } \\
\text { Tricholomataceae }\end{array}$ & $\begin{array}{l}\text { China, Japan, Taiwan, Europe, } \\
\text { North America, North Africa }\end{array}$ \\
\hline Cryptoporus volvatus & Veiled Polypore & $\begin{array}{l}\text { Basidiomycota } \\
\text { Agaricomycetes } \\
\text { Polyporales } \\
\text { Polyporaceae }\end{array}$ & Trunks of pine, fir and spruce \\
\hline Dichomitus squalens & $\begin{array}{l}\text { Common White-Rot } \\
\text { fungus }\end{array}$ & $\begin{array}{l}\text { Basidiomycota } \\
\text { Agaricomycetes } \\
\text { Polyporales } \\
\text { Polyporaceae }\end{array}$ & $\begin{array}{l}\text { Trunks of conifers such as pine } \\
\text { and larch }\end{array}$ \\
\hline Flammulina velutipes & $\begin{array}{l}\text { Golden Needle } \\
\text { mushroom }\end{array}$ & $\begin{array}{l}\text { Basidiomycota } \\
\text { Agaricomycetes } \\
\text { Agaricales } \\
\text { Physalacriaceae }\end{array}$ & $\begin{array}{l}\text { Subtropical zone such as Japan, } \\
\text { Russia, Australia and other } \\
\text { countries as well as Europe, } \\
\text { North America }\end{array}$ \\
\hline $\begin{array}{l}\text { Floccularia luteovirens } \\
\text { (syn. Armillaria } \\
\text { luteovirens) }\end{array}$ & $\begin{array}{l}\text { Scaly Yellow } \\
\text { mushroom }\end{array}$ & $\begin{array}{c}\text { Basidiomycota } \\
\text { Agaricomycetes } \\
\text { Agaricales } \\
\text { Tricholomataceae }\end{array}$ & $\begin{array}{l}\text { Meadow at altitudes of } \\
3000-4000 \mathrm{~m} \text { above sea level }\end{array}$ \\
\hline
\end{tabular}


Table 1. Cont.

\begin{tabular}{|c|c|c|c|}
\hline MM Species & Common Name & Taxonomy & $\begin{array}{c}\text { Geographic/Ecological } \\
\text { Distribution }\end{array}$ \\
\hline Ganoderma atrum & Black Ling-zhi & $\begin{array}{l}\text { Basidiomycota } \\
\text { Agaricomycetes } \\
\text { Polyporales } \\
\text { Polyporaceae }\end{array}$ & Tropical regions \\
\hline Ganoderma capense & Dark Ling-zhi & $\begin{array}{l}\text { Basidiomycota } \\
\text { Agaricomycetes } \\
\text { Polyporales } \\
\text { Polyporaceae }\end{array}$ & Tropical regions \\
\hline Ganoderma japonicum & Bloody Ling-zhi & $\begin{array}{l}\text { Basidiomycota } \\
\text { Agaricomycetes } \\
\text { Polyporales } \\
\text { Polyporaceae }\end{array}$ & $\begin{array}{l}\text { Majority in tropical and } \\
\text { subtropical regions of Asia, } \\
\text { Australia, Africa and America, } \\
\text { minority in temperate zone }\end{array}$ \\
\hline Ganoderma lucidum & $\begin{array}{l}\text { Reitake, } \\
\text { Ling-zhi, } \\
\text { Spirit Plant } \\
\text { Reishi }\end{array}$ & $\begin{array}{l}\text { Basidiomycota } \\
\text { Agaricomycetes } \\
\text { Polyporales } \\
\text { Polyporaceae }\end{array}$ & $\begin{array}{l}\text { Majority in tropical and } \\
\text { subtropical regions of Asia, } \\
\text { Australia, Africa and America, } \\
\text { minority in temperate zone }\end{array}$ \\
\hline $\begin{array}{l}\text { Ganoderma } \\
\text { microsporum }\end{array}$ & Small-Spored Ling-zhi & $\begin{array}{l}\text { Basidiomycota } \\
\text { Agaricomycetes } \\
\text { Polyporales } \\
\text { Polyporaceae }\end{array}$ & Subtropics zone \\
\hline Ganoderma lingzhi & Ling-zhi & $\begin{array}{l}\text { Basidiomycota } \\
\text { Agaricomycetes } \\
\text { Polyporales } \\
\text { Polyporaceae }\end{array}$ & China, North Korea, Japan \\
\hline Ganoderma sinensis & Zi-zhi & $\begin{array}{l}\text { Basidiomycota } \\
\text { Agaricomycetes } \\
\text { Polyporales } \\
\text { Polyporaceae }\end{array}$ & China, North Korea, Japan \\
\hline Ganoderma tsugae & Hemlock Varnish Shelf & $\begin{array}{l}\text { Basidiomycota } \\
\text { Agaricomycetes } \\
\text { Polyporales } \\
\text { Polyporaceae }\end{array}$ & Northern and Montaine zone \\
\hline Grifola frondosa & $\begin{array}{c}\text { Maitake } \\
\text { Hen of the Woods }\end{array}$ & $\begin{array}{l}\text { Basidiomycota } \\
\text { Agaricomycetes } \\
\text { Polyporales } \\
\text { Grifolaceae }\end{array}$ & Japan, China \\
\hline Hericium erinaceus & $\begin{array}{l}\text { Lion's Mane } \\
\text { mushroom, Bearded } \\
\text { Tooth mushroom, } \\
\text { Monkey-Head } \\
\text { mushroom }\end{array}$ & $\begin{array}{c}\text { Basidiomycota } \\
\text { Agaricomycetes } \\
\text { Russulales } \\
\text { Hericiaceae }\end{array}$ & $\begin{array}{l}\text { Broad-leaved forest or coniferous } \\
\text { and broad-leaved mixed forest in } \\
\text { northern temperate zone such as } \\
\text { Western Europe, North America, } \\
\text { China, Japan, Russia }\end{array}$ \\
\hline Inonotus obliquus & $\begin{array}{l}\text { Clinker Polypore, Birch } \\
\text { Conk, Chaga }\end{array}$ & $\begin{array}{l}\text { Basidiomycota } \\
\text { Agaricomycetes } \\
\text { Hymenochaetacles } \\
\text { Hymenochaetaceae }\end{array}$ & Russia, China \\
\hline Lentinula edodes & $\begin{array}{l}\text { Shiitake, Black Forest } \\
\text { mushroom, Golden } \\
\text { Oak mushroom }\end{array}$ & $\begin{array}{l}\text { Basidiomycota } \\
\text { Agaricomycetes } \\
\text { Agaricales } \\
\text { Omphalotaceae }\end{array}$ & $\begin{array}{c}\text { Distributed in an arc area on the } \\
\text { west side of the Pacific Ocean, } \\
\text { Japan, Papua New Guinea, Nepal, } \\
\text { the Mediterranean coast and } \\
\text { northern Africa }\end{array}$ \\
\hline
\end{tabular}


Table 1. Cont.

\begin{tabular}{|c|c|c|c|}
\hline MM Species & Common Name & Taxonomy & $\begin{array}{l}\text { Geographic/Ecological } \\
\text { Distribution }\end{array}$ \\
\hline Lignosus rhinocerotis & Tiger Milk mushroom & $\begin{array}{l}\text { Basidiomycota } \\
\text { Agaricomycetes } \\
\text { Polyporales } \\
\text { Polyporaceae }\end{array}$ & $\begin{array}{l}\text { China, Indonesia, Philippines, } \\
\text { Sri Lanka, Australia, Thailand, } \\
\text { Malaysia, Papua New Guinea and } \\
\text { rainforests of East Africa }\end{array}$ \\
\hline $\begin{array}{l}\text { Leucocalocybe } \\
\text { mongolica } \\
\text { (syn. Tricholoma } \\
\text { mongolicum) }\end{array}$ & Mongolia mushroom & $\begin{array}{c}\text { Basidiomycota } \\
\text { Basidiomycetes } \\
\text { Agaricales } \\
\text { Agaricales incertae sedis }\end{array}$ & Inner Mongolia in China \\
\hline Marasmius oreades & Fairy Ring mushroom & $\begin{array}{l}\text { Basidiomycota } \\
\text { Agaricomycetes } \\
\text { Agaricales } \\
\text { Marasmiaceae }\end{array}$ & North America and Asia \\
\hline Morchella esculenta & $\begin{array}{l}\text { Common Morel, } \\
\text { Yellow Morel, Sponge } \\
\text { Morel }\end{array}$ & $\begin{array}{l}\text { Ascomycota } \\
\text { Pezizomycetes } \\
\text { Pezizales } \\
\text { Morohellaceae }\end{array}$ & $\begin{array}{l}\text { Widely cultured over the world } \\
\text { such as France, Germany, } \\
\text { America, India, China, Russia, } \\
\text { Sweden, Mexico, Spain, } \\
\text { Czechoslovakia and Pakistan }\end{array}$ \\
\hline Morchella conica & $\begin{array}{l}\text { Black Morel, Sponge } \\
\text { mushroom }\end{array}$ & $\begin{array}{l}\text { Ascomycota } \\
\text { Pezizomycetes } \\
\text { Pezizales } \\
\text { Morohellaceae }\end{array}$ & $\begin{array}{l}\text { Distributed under broad-leaved } \\
\text { forest, coniferous broad-leaved } \\
\text { mixed forest, forest edge open } \\
\text { space and weeds }\end{array}$ \\
\hline $\begin{array}{l}\text { Naematelia aurantialba } \\
\text { (syn. Tremella } \\
\text { aurantialba) }\end{array}$ & Golden Tremella & $\begin{array}{l}\text { Basidiomycota } \\
\text { Tremellomycetes } \\
\text { Tremellales } \\
\text { Naemateliaceae }\end{array}$ & $\begin{array}{l}\text { Mountain forest of quercus, } \\
\text { mutualism with Stereum spp. }\end{array}$ \\
\hline $\begin{array}{l}\text { Ophiocordyceps } \\
\text { sinensis }\end{array}$ & $\begin{array}{l}\text { Caterpillar fungus, } \\
\text { Himalaya Viagra }\end{array}$ & $\begin{array}{c}\text { Ascomycota } \\
\text { Sordariomycetes } \\
\text { Hypocreales } \\
\text { Ophiocordycipitaceae }\end{array}$ & Southwest China, Nepal \\
\hline Pholiota adiposa & Chestnut mushroom & $\begin{array}{l}\text { Basidiomycota } \\
\text { Agaricomycetes } \\
\text { Agaricales } \\
\text { Strophariaceae }\end{array}$ & $\begin{array}{l}\text { Distributed on the dead willows } \\
\text { in the forest in China }\end{array}$ \\
\hline $\begin{array}{l}\text { Pleurotus } \\
\text { citrinopileatus }\end{array}$ & $\begin{array}{l}\text { Golden Oyster } \\
\text { mushroom, } \\
\text { Tamogitake }\end{array}$ & $\begin{array}{l}\text { Basidiomycota } \\
\text { Agaricomycetes } \\
\text { Agaricales } \\
\text { Pleurotaceae }\end{array}$ & Widely cultured all over the world \\
\hline Pleurotus ostreatus & Oyster mushroom & $\begin{array}{l}\text { Basidiomycota } \\
\text { Agaricomycetes } \\
\text { Agaricales } \\
\text { Pleurotaceae }\end{array}$ & Widely cultured all over the world \\
\hline $\begin{array}{l}\text { Cerioporus squamosus } \\
\text { (syn. Polyporus } \\
\text { squamosus) }\end{array}$ & $\begin{array}{l}\text { Dryad's Saddle, } \\
\text { Pheasant's Back } \\
\text { mushroom }\end{array}$ & $\begin{array}{l}\text { Basidiomycota } \\
\text { Agaricomycetes } \\
\text { Polyporales } \\
\text { Polyporaceae }\end{array}$ & $\begin{array}{c}\text { Widely distributed in hardwood } \\
\text { forest of North America, Australia, } \\
\text { Asia and Europe }\end{array}$ \\
\hline Poria cocos & Fuling, China Root & $\begin{array}{l}\text { Basidiomycota } \\
\text { Agaricomycetes } \\
\text { Polyporales } \\
\text { Laetiporaceae }\end{array}$ & $\begin{array}{l}\text { Parasitic on the roots of Pinaceae } \\
\text { plants, mainly distributed in } \\
\text { China }\end{array}$ \\
\hline $\begin{array}{l}\text { Rhodonia placenta } \\
\text { (syn. Postia placenta) }\end{array}$ & Rosy Crust & $\begin{array}{l}\text { Basidiomycota } \\
\text { Agaricomycetes } \\
\text { Polyporales } \\
\text { Dacryobolaceae }\end{array}$ & $\begin{array}{l}\text { Widely distributed all over the } \\
\text { world }\end{array}$ \\
\hline
\end{tabular}


Table 1. Cont.

\begin{tabular}{|c|c|c|c|}
\hline MM Species & Common Name & Taxonomy & $\begin{array}{c}\text { Geographic/Ecological } \\
\text { Distribution }\end{array}$ \\
\hline $\begin{array}{l}\text { Pseudosperma } \\
\text { umbrinellum } \\
\text { (syn. Inocybe } \\
\text { umbrinella) }\end{array}$ & Fibrous Hat & $\begin{array}{l}\text { Basidiomycota } \\
\text { Agaricomycetes } \\
\text { Agaricales } \\
\text { Inocybaceae }\end{array}$ & France \\
\hline Russula delica & Milk-White Brittlegill & $\begin{array}{l}\text { Basidiomycota } \\
\text { Agaricomycetes } \\
\text { Russulales } \\
\text { Russulaceae }\end{array}$ & Taiga forest and mixed forests \\
\hline Russula lepida & Rosy Russula & $\begin{array}{l}\text { Basidiomycota } \\
\text { Agaricomycetes } \\
\text { Russulales } \\
\text { Russulaceae }\end{array}$ & $\begin{array}{l}\text { Widely distributed all over the } \\
\text { world }\end{array}$ \\
\hline Sarcodon aspratus & Black Tiger Paw & $\begin{array}{l}\text { Basidiomycota } \\
\text { Agaricomycetes } \\
\text { Thelephorales } \\
\text { Thelephoraceae }\end{array}$ & Southwest of China \\
\hline $\begin{array}{l}\text { Schizophyllum } \\
\text { commune }\end{array}$ & Split Gill & $\begin{array}{l}\text { Basidiomycota } \\
\text { Agaricomycetes } \\
\text { Agaricales } \\
\text { Schizophyllaceae }\end{array}$ & $\begin{array}{l}\text { Widely distributed all over the } \\
\text { world }\end{array}$ \\
\hline $\begin{array}{l}\text { Stropharia } \\
\text { rugosoannulata }\end{array}$ & $\begin{array}{l}\text { Wine Cap Stropharia, } \\
\text { Garden Giant, } \\
\text { Burgundy mushroom, } \\
\text { King Stropharia }\end{array}$ & $\begin{array}{l}\text { Basidiomycota } \\
\text { Agaricomycetes } \\
\text { Agaricales } \\
\text { Strophariaceae }\end{array}$ & Europe, North America, Asia \\
\hline $\begin{array}{l}\text { Taiwanofungus } \\
\text { camphoratus } \\
\text { (syn. Antrodia } \\
\text { camphorate) }\end{array}$ & $\begin{array}{l}\text { Poroid Brown-rot } \\
\text { fungus, Stout Camphor } \\
\text { fungus }\end{array}$ & $\begin{array}{c}\text { Basidiomycota } \\
\text { Agaricomycetes } \\
\text { Polyporales incertae sedis }\end{array}$ & $\begin{array}{l}\text { Mountain forest in Taiwan with } \\
\text { altitudes of } 450-2000 \mathrm{~m}\end{array}$ \\
\hline $\begin{array}{c}\text { Trametes versicolor } \\
\text { (syn. Polystictus } \\
\text { versicolor) }\end{array}$ & Turkey Tail fungus & $\begin{array}{c}\text { Basidiomycota } \\
\text { Agaricomycetes } \\
\text { Polyporales } \\
\text { Polyporaceae }\end{array}$ & $\begin{array}{l}\text { Global distribution; Broad-leaf } \\
\text { woods }\end{array}$ \\
\hline $\begin{array}{l}\text { Tropicoporus linteus } \\
\text { (syn. Phellinus } \\
\text { linteus) }\end{array}$ & $\begin{array}{l}\text { Mesima, Black Hoof } \\
\text { fungus }\end{array}$ & $\begin{array}{c}\text { Basidiomycota } \\
\text { Agaricomycetes } \\
\text { Hymenochaetales } \\
\text { Hymenochaetaceae }\end{array}$ & $\begin{array}{c}\text { Distributed on the dead trees and } \\
\text { trunks in China }\end{array}$ \\
\hline $\begin{array}{l}\text { Xerocomellus } \\
\text { chrysenteron } \\
\text { (syn. Xerocomus } \\
\text { Chrysenteron) }\end{array}$ & Red Cracking Bolete & $\begin{array}{c}\text { Basidiomycota } \\
\text { Agaricomycetes } \\
\text { Agaricales } \\
\text { Agaricales incertae sedis }\end{array}$ & China \\
\hline Xylaria hypoxylon & $\begin{array}{l}\text { Candlestick fungus, } \\
\text { Candlesnuff fungus, } \\
\text { Carbon Antlers, Stag's } \\
\text { Horn fungus }\end{array}$ & $\begin{array}{c}\text { Ascomycota } \\
\text { Sordariomycetes } \\
\text { Xylariales } \\
\text { Xylariaceae }\end{array}$ & Northern Europe \\
\hline Xylaria nigripes & Dead Moll's Fingers & $\begin{array}{c}\text { Ascomycota } \\
\text { Sordariomycetes } \\
\text { Xylariales } \\
\text { Xylariaceae }\end{array}$ & China, mutualism with white ant \\
\hline Volvariella volvacea & Straw mushroom & $\begin{array}{c}\text { Basidiomycota } \\
\text { Basidiomycetes } \\
\text { Agaricales } \\
\text { Pluteaceae }\end{array}$ & China, East Asia, Southeast Asia \\
\hline
\end{tabular}


Some of these MM species have been used as herbal medicine for centuries, including Ganoderma lucidum, Ganoderma lingzhi, Lentinula edodes, Inonotus obliquus, Fomitopsis officinalis, Piptoporus betulinus, and Fomes fomentarius [7,17]. While these mushrooms have attracted most of the medical attention among the MMs, other species in multiple genera have also shown immunomodulatory and anti-tumor effects, such as those in genera Agaricus, Albatrellus, Antrodia, Calvatia, Clitocybe, Cordyceps, Flammulina, Fomes, Funlia, Ganoderma, Inocybe, Inonotus, Lactarius, Phellinus, Pleurotus, Russula, Schizophyllum, Suillus, Trametes, and Xerocomus [12].

Figure 1 shows a few representative medicinal mushroom species in their natural habitats. Some medicinal mushrooms are only found in the wild, e.g., the ectomycorrhizal mushrooms Boletus edulis and Russula lepida. However, a large number of medicinal mushrooms are also commercially cultivated, including Shiitake, Ling-zhi, and Lion's Mane. Figure 2 shows a few representative medicinal mushrooms under cultivation.

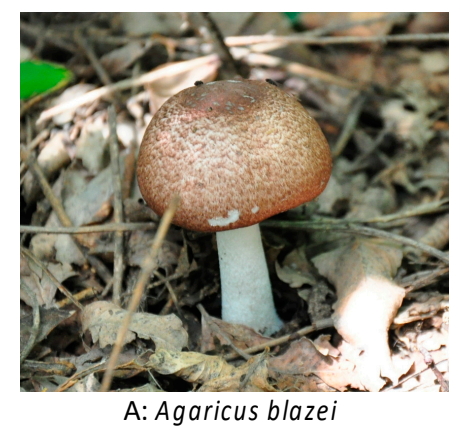

(syn. Agaricus brasiliensis)

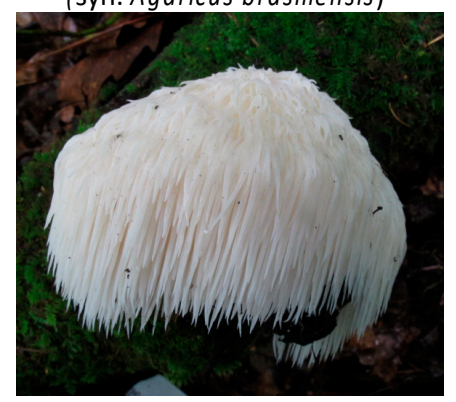

D. Hericium erinaceus

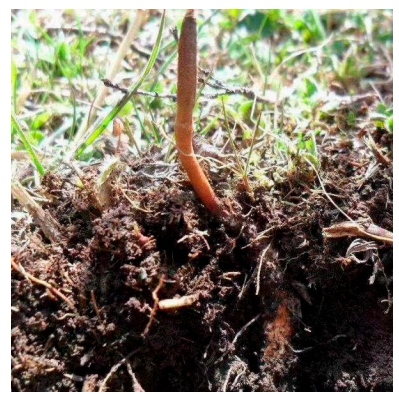

B: Ophiocordyceps sinensis

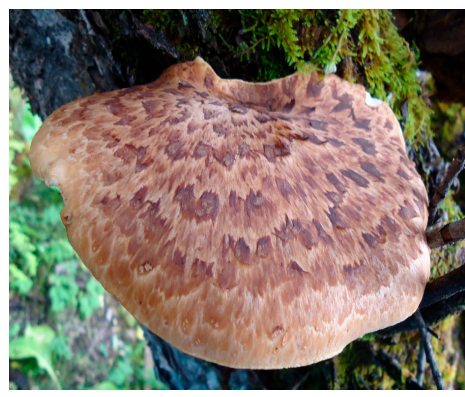

E. Cerioporus squamosus (syn. Polyporus squamosus

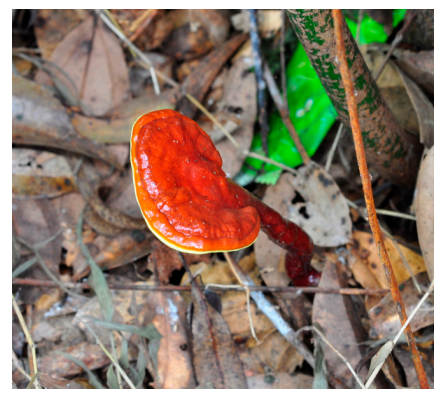

C. Ganoderma lucidum

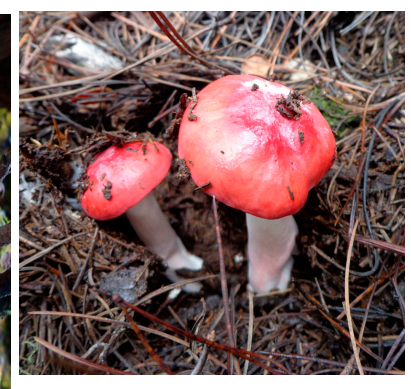

F. Russula lepida

Figure 1. A few representative medicinal mushrooms from the wild. 


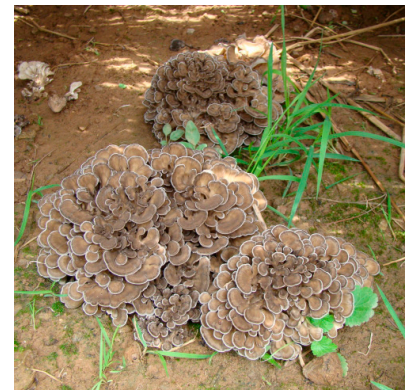

A. Grifola frondosa

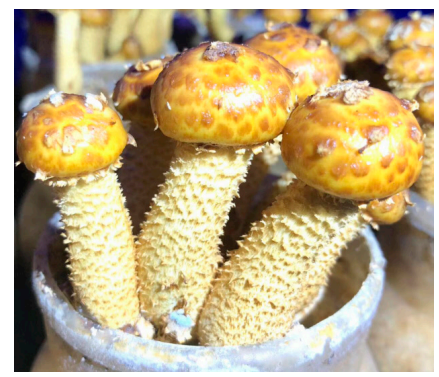

D. Pholiota adiposa

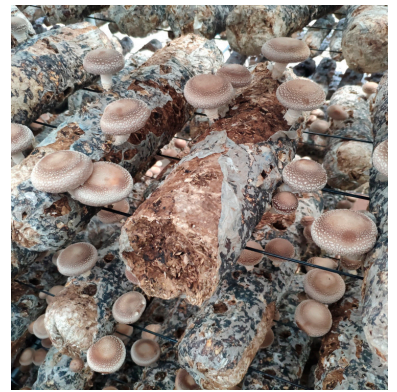

B. Lentinula edodes

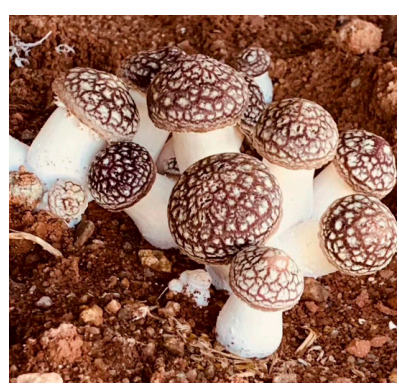

E. Stropharia rugosoannulata

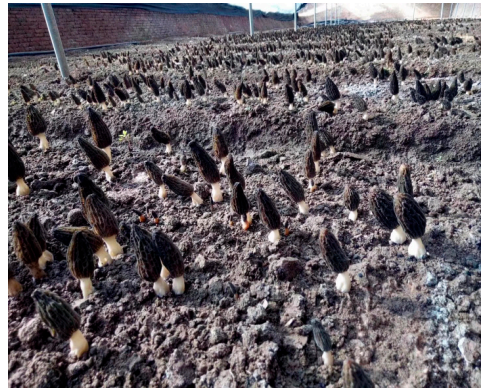

C. Morchella esculenta

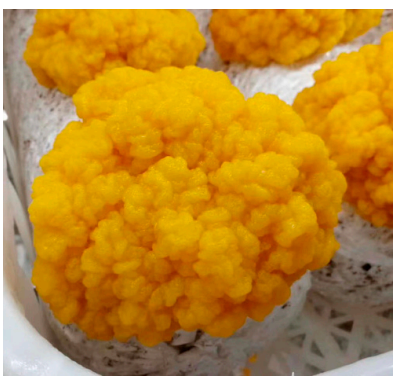

F. Naematelia aurantialba (syn. Tremella aurantialba)

Figure 2. A few representative cultivated medicinal mushrooms.

\section{Immunomodulatory Compounds and Commercial Products of Medicinal Mushrooms}

As shown above, there is a large number of medicinal mushrooms in diverse taxonomic groups. Some of these medicinal mushrooms are commercially cultivated for food but there is an increasing trend for developing the immune-active compounds from these cultivated mushrooms into nutraceuticals. Tables 2-5 summarize the major groups of bioactive compounds in medicinal mushrooms and their demonstrated immunomodulatory effects to specific pathologies, including the relevant references.

The main classes of compounds from medicinal mushrooms with immunomodulatory properties are terpenes and terpenoids, lectins, fungal immunomodulatory proteins (FIPs), and polysaccharides (particularly $\beta$-D-glucans, but also include polysaccharopeptides and polysaccharide proteins) [1]. Below we describe specific examples in each of these groups.

\subsection{Polysaccharides}

Among the bioactive compounds derived from mushrooms with immunomodulatory activity, those based on polysaccharides, with or without side chain modifications (including polysaccharopeptides and polysaccharide proteins) are the most reported during the last several decades [18]. Table 2 presents a list of polysaccharides from medicinal mushrooms that have shown immunomodulatory activities. Among the reported polysaccharides with immunomodulatory and antitumor activities, the best-known is lentinan, isolated from shiitake (L. edodes), as well as schizophyllan from Schizophyllum commune. Both lectinan and schizophyllan contain $\beta$-1,3-D-glucans with $\beta-1,6$ branches. Specifically, lentinan showed immunomodulatory properties against gastric cancer while schizophyllan was effective against head and neck cancer. Both products have been licensed and approved in Japan since 1986 for clinical use, in combination with chemotherapy against the two respective cancers $[19,20]$. 
Other polysaccharide-based compounds showing immunomodulatory properties have a similar core polysaccharide chemical structure but contain different branching linkages and/or branches with different conjugates. These polysaccharide-conjugate complexes are called heteroglucans, with $\alpha(1-4)$ and $\beta(1-3)$ glycosidic linkages to protein components. For example, in the presence of fucose (a hexose deoxy sugar with the chemical formula $\mathrm{C} 6 \mathrm{H} 12 \mathrm{O} 5)$, the turkey tail mushroom Trametes versicolor produces a Krestin bound $\beta$-glucan polysaccharide K (PSK). PSK is commercially produced from this mushroom in Japan and has been approved for clinical use since 1977 [21]. Several subsequent reports confirmed the effectiveness of PSK as an adjuvant to conventional cancer therapies through inhibition of cancer metastasis [22], induction of cancer cell apoptosis [23], improvement of inflammatory cytokines gene expression [24,25].

Another compound isolated from T. versicolor is a polysaccharide peptide (PSP). PSP contains rhamnose and arabinose, two monosaccharides not found in PSK. In addition, the conjugated protein was also different. PSP has been commercially available in the Chinese market since 1987 [21]. It has been documented to improve the quality of life in cancer patients by providing substantial pain relief and enhancing immune status in $70-97 \%$ of patients with stomach, esophagus, lung, ovary and cervical cancers. Specifically, PSP has been shown to be capable of boosting immune cell production, ameliorating chemotherapy symptoms, and enhancing tumor infiltration by dendritic and cytotoxic T-cells [26].

Two other well-known polysaccharide-protein complexes produced by Macrocybe gigantea (syn. Tricholoma giganteum) and Agaricus brazei, respectively, have also shown immunomodulatory effects. A polysaccharide-protein complex (PSPC) isolated from T. giganteum showed that it could help restore and improve the phagocytic function of macrophages in tumor-bearing mice [13,27]. Similarly, AbM isolated from A. brazei contains diverse polysaccharide-protein complexes with different chemical linkages such as $\beta-1,6$-glucan, $\alpha-1,6-$ and $\alpha-1,4-$ glucan, glucomannan and $\beta-1,3$-glucan. AbM has been shown to have immunomodulatory and antineoplastic properties [28]. Polysaccharides and polysaccharide-protein complexes from other medicinal mushrooms that have shown immunomodulatory effects are listed in Table 2. 
Table 2. Major immunomodulatory polysaccharides from medicinal mushrooms and their immunomodulatory effects.

\begin{tabular}{|c|c|c|c|}
\hline Source & Active Compound & Immunomodulatory Effect & Refs \\
\hline $\begin{array}{l}\text { Agaricus blazei } \\
\text { (syn. Agaricus brasiliensis) }\end{array}$ & $\begin{array}{l}\text { Heteroglycan, Glycoprotein, Glucomannan-protein } \\
\text { complex, } \beta-1,3 \text {-D-glucan, with } \beta-1,6-\text { - }- \text { glucan branch }\end{array}$ & $\begin{array}{l}\text { Stimulates Natural Killer (NK) cells, macrophages, dendritic cells, and granulocytes; } \\
\text { induction of Tumor Necrosis Factor (TNF), Interferon (IFN)- } \gamma \text {, and Interleukin (IL)-8 } \\
\text { production }\end{array}$ & [29] \\
\hline Auricularia auricula-judae & $\begin{array}{l}\text { AF1 } \beta-1,3-D-g l u c a n \text { main chain with two } \beta-1,6-D-g l u c o s y l \\
\text { residues }\end{array}$ & Induces apoptosis of cancer cell & [30] \\
\hline $\begin{array}{l}\text { Gymnopus dryophilus } \\
\text { (syn. Collybia dryophila) }\end{array}$ & $\beta$-D-glucan & Inhibits NO production in activated macrophages & [31] \\
\hline Ophiocordyceps sinensis & $\beta$-D-glucan, heteroglycan, cordyglucan & Increase in IL-5 induction with decrease in IL-4 and IL-17 & [32] \\
\hline Cryptoporus volvatus & $\beta$-1,3-D-Glucan & Decreases in TLR2 and activate NF- $\mathrm{KB}$ & [33] \\
\hline Flammulina velutipes & $\begin{array}{l}\text { Glycoprotein, Flammulina velutipes peptidoglycan (FVP), } \\
\beta-1,3-\mathrm{D}-\text { glucan }\end{array}$ & Increases NO, IL-1 production, and TNF- $\alpha$ secretion & [34] \\
\hline Ganoderma lucidum & Ganoderan, Heteroglycan, mannoglucan, glycopeptide & Stimulates TNF- $\alpha$, IL-1, IFN- $\gamma$ production, activate NF-kB. & [35] \\
\hline Grifola frondosa & $\begin{array}{l}\text { Grifolan (1-6-monoglucosyl-branched } \beta \text {-1,3-D-glucan), } \\
\text { proteoglycan, heteroglycan, galactomannan }\end{array}$ & Macrophage activation, induction of IL-1, IL- 6 , and TNF- $\alpha$ secretion & [36] \\
\hline Hericium erinaceus & $\begin{array}{l}\text { Heteroglycan, heteroglycan-peptide, } \beta-1,3 \\
\text { branched- } \beta-1,2 \text {-mannan }\end{array}$ & Induces NO production, increase expression of TNF- $\alpha$, IL-1 $\beta$, IL-12 & [15] \\
\hline Inonotus obliquus & $\beta$-D-glucan & $\begin{array}{l}\begin{array}{l}\text { Enhance expression of IL-1 } \beta, \text { IL-6, TNF- } \alpha \text {, and inducible nitric oxide synthase (iNOS) in } \\
\text { macrophages }\end{array}\end{array}$ & [37] \\
\hline $\begin{array}{l}\text { Lentinula edodes } \\
\text { (syn. Lentinus edodes) }\end{array}$ & $\begin{array}{l}\text { Lentinan, glucan, mannoglucan, proteoglycan, } \\
\beta-(1-6) \text {-D-glucan, } \alpha-(1-3) \text {-D-glucan }\end{array}$ & $\begin{array}{l}\text { Induces non-specific cytotoxicity in macrophage and enhance cytokine production } \\
\text { Induces cytotoxic effect on a breast cancer cell line }\end{array}$ & {$[38-40]$} \\
\hline Lentinus squarrosulus & Glucan & Activation of macrophages, splenocytes and thymocytes & [41] \\
\hline Morchella esculenta & Galactomannan, $\beta$-1,3-D-glucan & Macrophage activation, activate NF- $\mathrm{kB}$ & [42] \\
\hline Morchella conica & Galactomannan & Induces NO, IL-1 $\beta$, IL-6 production & [43] \\
\hline $\begin{array}{l}\text { Naematelia aurantialba } \\
\text { (syn. Tremella aurantialba) }\end{array}$ & Heteroglycan & Enhances mouse spleen lymphocyte proliferation & [44] \\
\hline $\begin{array}{l}\text { Pleurotus sp. 'Florida' } \\
\text { (syn. Pleurotus florida) }\end{array}$ & $\alpha-1,6$-glucan and $\alpha-1,3-, \beta-1,6$-D-glucan & Stimulates macrophages, splenocytes and thymocytes & {$[45,46]$} \\
\hline Pleurotus ostreatus & Pleuran, heterogalactan, proteoglycan & Induces IL- 4 and IFN- $\gamma$ production & [47] \\
\hline Poria cocos & $\beta$-pachyman, $\beta$-Glucan, $\beta$-1,3-D-glucan, $\alpha$-1, 3-D-glucan & Promotes the immune reaction; increases the expression of cytokines & {$[48,49]$} \\
\hline Sarcodon aspratus & Fucogalactan, 1,6- $\alpha$-D-glucopyranosyl residue & Increases the release of TNF- $\alpha$ and NO in macrophage & [50] \\
\hline
\end{tabular}


Table 2. Cont.

\begin{tabular}{|c|c|c|c|}
\hline Source & Active Compound & Immunomodulatory Effect & Refs \\
\hline Schizophyllum commune & Schizophyllan, 1,6-monoglucosyl branched $\beta$-1, 3-D-glucan & Activation of T cell, increases interleukin, and TNF- $\alpha$ production & [51] \\
\hline Sparassis crispa & $\beta$-Glucan & Enhances IL- 6 and INF- $\gamma$ production & [52] \\
\hline $\begin{array}{l}\text { Taiwanofungus camphoratus } \\
\text { (syn. Antrodia camphorate) }\end{array}$ & $\begin{array}{l}\beta-1,3-\mathrm{D}-\text {-Gluco-pyranans with } \beta-1,6-\mathrm{D}-\text { glucosyl branches, } \\
\text { proteoglycan }\end{array}$ & Induction of INF- $\gamma$, TNF- $\alpha$ & [53] \\
\hline $\begin{array}{l}\text { Tropicoporus linteus (syn. } \\
\text { Phellinus linteus) }\end{array}$ & Acidic polysaccharides & $\begin{array}{l}\text { Activation of murine B cells, Induces IL- } 12 \text { and IFN- } \gamma \text { production, } \\
\text { Blocks NF- } \mathrm{B}, \mathrm{TNF}-\alpha, \text { IL- } 1 \alpha \text {, IL- } 1 \beta \text {, and IL- } 4 \text { production }\end{array}$ & [54] \\
\hline Trametes versicolor & $\begin{array}{l}\text { Polysaccharide peptide Krestin (PSK), } \beta \text {-1,3-glycosidic } \\
\text { bond with } \beta \text {-1,6-glycosidic branches }\end{array}$ & Increases the expression of cytokines; stimulates the macrophage phagocytes & {$[1,55]$} \\
\hline Tremella fuciformis & $\begin{array}{l}\text { Acidic glucuronoxylomannan } \alpha \text {-1,3-D-mannan backbone } \\
\text { with } \beta \text {-linked D-glucuronic acid }\end{array}$ & Induces human monocytes to express interleukins & {$[56,57]$} \\
\hline $\begin{array}{c}\text { Macrocybe gigantea } \\
\text { (syn. Tricholoma giganteum) }\end{array}$ & Polysaccharide-protein complex (PSPC) & $\begin{array}{l}\text { Increases phagocytic function of macrophages by activating macrophages to release } \\
\text { mediators such as NO and TNF- } \alpha \text { and inhibits S180 and HL-60 cells }\end{array}$ & {$[13,27]$} \\
\hline Xylaria nigripes & $\beta$-Glucan & Inhibits NO, IL-1 $\beta$, IL-6, TNF- $\alpha$, and IFN- $\gamma$ production & [58] \\
\hline
\end{tabular}




\subsection{Mushroom Proteins and Protein-Conjugate Complexes}

Mushroom proteins and protein-conjugate complexes are also well-known as immunomodulatory compounds. Similar to the polysaccharide-based compounds, these protein-based immunomodulatory compounds in medicinal mushrooms can also be grouped into different categories. Here, these compounds are grouped into two major categories: fungal immunomodulatory proteins (FIPs) and lectins. FIPs differ from lectins by having no conjugate while each lectin contains specific carbohydrates conjugated to a polypeptide.

Table 3 lists all the lectins from medicinal mushrooms isolated so far that have shown immunomodulatory effects. These lectins have been shown to be capable of stimulating nitrite production, upregulating the expressions of tumor necrosis factor (TNF)- $\alpha$ and interleukins, activating lymphocytes, and promoting the production of macrophage-activating factors etc. The medicinal mushroom species containing such lectins are very diverse, including Floccularia luteovirens (syn. Armillaria luteovirens), Ganoderma capense, Grifola frondosa, Pseudosperma umbrinellum (syn. Inocybe umbrinella), Pholiota adipose, Pleurotus citrinopileatus, Russula delica, S. commune, Leucocalocybe mongolica (syn. Tricholoma mongolicum), Volvariella volvacea, and Xerocomus spadiceus [59-64]. In addition, several mushroom lectins have also shown potent antiviral, mitogenic, antimicrobial and antioxidant activities [59,63,65-69].

Similarly, a large number FIPs have been identified. The FIP names, the medicinal mushrooms that produce them, and evidence for their specific immunomodulatory effects are presented in Table 4. Among these, the best known is probably Ling-Zhi-8 from G. lucidum which acts as an immunosuppressive agent [1]. In addition, aside from immunomodulation, many FIPs have also shown antitumor activities in pharmacological tests, including the inhibition of cell growth and proliferation, the induction of apoptosis and autophagy, and the reduction of invasion and migration of tumor cells. At present, most of these tests are conducted using tissue cultures. Further tests using animal models and clinical trials are needed in order to confirm their safety and efficacy in humans. If confirmed, these FIPs could be more efficiently produced and commercialized through genetic engineering for clinical use. 
Table 3. Major immunomodulatory lectins from medicinal mushrooms and their immunomodulatory effects.

\begin{tabular}{|c|c|c|c|}
\hline Source & Lectin name & Immunomodulatory effect & Refs \\
\hline Agaricus bisporus & Agaricus bisporus lectin (ABL) & Stimulate mice splenocytes mitogenicity and inhibit proliferation of L1210 and HT-29 cells & {$[70,71]$} \\
\hline Agrocybe aegerita & Agrocybe aegerita lectin (AAL) & Inhibit proliferation of 4T1, HeLa, SW480 SGC7901, MGC803, BGC823, HL-60 and S180 cells & {$[72,73]$} \\
\hline Amanita phalloides & - & Inhibit proliferation of L1210 cells & [74] \\
\hline $\begin{array}{l}\text { Floccularia luteovirens } \\
\text { (syn. Armillaria luteovirens) }\end{array}$ & Armillaria luteovirens lectin (ALL) & $\begin{array}{l}\text { Stimulate mice splenocytes mitogenicity and inhibit proliferation of L1210, Mouse } \\
\text { myeloma MBL2 and HeLa cells }\end{array}$ & [75] \\
\hline Boletus edulis & Boletus edulis lectin (BEL) & $\begin{array}{l}\text { Stimulate mice splenocytes mitogenicity and inhibit proliferation of human hepatocyte } \\
\text { carcinoma G2 (HepG2) and HT-29 cells }\end{array}$ & [76] \\
\hline Boletus speciosus & Boletus speciosus hemagglutinin (BSH) & Inhibit proliferation of HepG2 and L1210 cells & [77] \\
\hline Clitocybe nebularis & Clitocybe nebularis lectin (CNL) & Inhibit proliferation of human leukemic T cells & [78] \\
\hline Flammulina velutipes & Flammulina velutipes agglutinin (FVA) & Stimulate mice splenocytes mitogenicity and inhibit proliferation of L1210 cells & [79] \\
\hline Ganoderma capense & - & Stimulate mice splenocytes mitogenicity and inhibit proliferation of L1210, M1, HepG2 cells & [62] \\
\hline Grifola frondosa & Grifola frondosa lectin (GFL) & Inhibit proliferation of HeLa & [80] \\
\hline $\begin{array}{l}\text { Hericium erinaceus } \\
\text { (Syn.Hericium erinaceum) }\end{array}$ & Hericium erinaceus agglutinin (HEA) & Inhibit proliferation of HepG2 and human breast cancer MCF7 cells & [81] \\
\hline Kurokawa leucomelas & Kurokawa leucomelas KL-15 & Inhibit proliferation of U937 cells & [82] \\
\hline Lactarius flavidulus & Lactarius flavidulus lectin (LFL) & Inhibit proliferation of HepG2 and L1210 cells & [83] \\
\hline Lignosus rhinocerotis & Lignosus rhinocerotis lectin (LRL) & Inhibit proliferation of HeLa, MCF7 and A549 cells & [84] \\
\hline Marasmius oreades & Marasmius oreades agglutinin (MOA) & Inhibit proliferation of SW480, HepG2 and NIH-3T3 cells & [85] \\
\hline Pholiota adiposa & Pholiota adiposa lectin (PAL) & Inhibit proliferation of HepG2 and MCF7 cells & [61] \\
\hline Pleurotus citrinopileatus & - & Stimulate mice splenocytes mitogenicity and inhibit proliferation of S180 cells & [59] \\
\hline Pleurotus eous & Pleurotus eous lectin (PEL) & Inhibit proliferation of MCF7, K562 and HepG2 & [86] \\
\hline $\begin{array}{l}\text { Cerioporus squamosus } \\
\text { (syn. Polyporus squamosus) }\end{array}$ & Polyporus squamosus lectin 1a (PSL1a) & Inhibit proliferation of HeLa cells & [87] \\
\hline $\begin{array}{l}\text { Pseudosperma umbrinellum } \\
\text { (syn. Inocybe umbrinella) }\end{array}$ & Inocybe umbrinella lectin (IUL) & Inhibit proliferation of HepG2 and MCF7 cells & [60] \\
\hline Russula delica & - & Inhibit proliferation of HepG2 and MCF7 cells & [64] \\
\hline
\end{tabular}


Table 3. Cont

\begin{tabular}{|c|c|c|c|}
\hline Source & Lectin name & Immunomodulatory effect & Refs \\
\hline Russula lepida & Russula lepida lectin (RLL) & Inhibit proliferation of HepG2 and MCF7 cells & [88] \\
\hline Schizophyllum commune & Schizophyllum commune lectin (SCL) & $\begin{array}{l}\text { Stimulate mice splenocytes mitogenicity and inhibit proliferation of KB, HepG2 and } \\
\text { S180 cells }\end{array}$ & {$[63,89]$} \\
\hline Stropharia rugosoannulata & Stropharia rugosoannulata lectin (SRL) & Inhibit proliferation of HepG2 and L1210 cells & [90] \\
\hline $\begin{array}{l}\text { Leucocalocybe mongolica } \\
\text { (syn. Tricholoma mongolicum) }\end{array}$ & $\begin{array}{l}\text { Tricholoma mongolicum lectin } 1 \text { (TML-1), } \\
\text { Tricholoma mongolicum lectin } 2 \text { (TML-2) }\end{array}$ & Inhibit proliferation of S180 cells & [91] \\
\hline Volvariella volvacea & Volvariella volvacea lectin (VVL) & Inhibit proliferation of S180 cells and enhance IL-2 and IFN- $\gamma$ transcriptions & {$[92,93]$} \\
\hline $\begin{array}{l}\text { Xerocomellus chrysenteron } \\
\text { (syn. Xerocomus chrysenteron) }\end{array}$ & Xerocomus chrysenteron lectin (XCL) & Inhibit proliferation of NIH-3T3 and HeLa cells & [94] \\
\hline Xylaria hypoxylon & Xylaria hypoxylon lectin (XHL) & Inhibit proliferation of HepG2 cells & [95] \\
\hline
\end{tabular}


Table 4. Major fungal immunomodulatory proteins (FIPs) from medicinal mushrooms and their immunomodulatory effects.

\begin{tabular}{|c|c|c|c|}
\hline FIP Name & Source & Immunomodulatory Effect & Refs \\
\hline FIP-aca & $\begin{array}{l}\text { Taiwanofungus camphoratus } \\
\text { (Syn. Antrodia camphorate) }\end{array}$ & $\begin{array}{l}\text { Induce expression of different cytokines (IL-1b, IL-6, IL-12, TNF- } \alpha \text { ) and chemokines (CCL3, } \\
\text { CCL4, CCL5, CCL10) }\end{array}$ & [96] \\
\hline FIP-cru1 & Chroogomphis rutilus & Stimulate the proliferation of murine splenocytes and enhanced the secretion of IL-2 & [97] \\
\hline FIP-dsq (FIP-dsq2) & Dichomitus squalens & Induce apoptosis and interrupt migration of A549 cells & [98] \\
\hline FIP-fve & Flammulina velutipes & $\begin{array}{c}\text { Stimulate mitogenesis in human peripheral lymphocytes, suppress systemic anaphylaxis } \\
\text { reaction, enhance transcription of IL-3, INF-g }\end{array}$ & [99] \\
\hline FIP-gja & Ganoderma japonicum & - & GenBank: AAX98241 \\
\hline FIP-gat & Ganoderma atrum & - & [100] \\
\hline FIP-glu1 (LZ-8) & Ganoderma lucidum & Enhance transcription of IL-2, IL-3, IL-4, IFN-g, TNF- $\alpha$ & [101] \\
\hline FIP-gmi & Ganoderma microsporum & Down regulation of TNF- $\alpha$ & [102] \\
\hline FIP-gsi & Ganoderma sinensis & Enhance production of IL-2, IL-3, IL-4, INF-g, TNF-a & [103] \\
\hline FIP-gts & Ganoderma tsugae & $\begin{array}{l}\text { Induce cytokine secretion, cellular proliferation of human peripheral mononuclear cells } \\
\text { (HPBMCs), enhance IFN-g expression }\end{array}$ & [104] \\
\hline FIP-glu2 (LZ-9) & Ganoderma lucidum & Activate THP-1 macrophages and induce pro-inflammatory cytokine transcription & [105] \\
\hline FIP-SN15 & Intrageneric shuffled library & Induce U-251 MG cells apoptosis & [106] \\
\hline FIP-Irh & Lignosus rhinocerotis & Inhibit the proliferation of MCF7, HeLa and A549 cancer cell lines & [84] \\
\hline FIP-pcp & Poria cocos & Enhance production of IL-1b, IL-6, IL-18, TNF-a, NO & [107] \\
\hline FIP-ppl & Postia placenta & $\begin{array}{l}\text { Stimulate mouse splenocyte cell proliferation and enhance interleukin-2 (IL-2) release, } \\
\text { inhibit proliferation and induce apoptotic effects on gastric tumor cells (MGC823) }\end{array}$ & [108] \\
\hline FIP-tve2 (FIP-tvc) & Trametes versicolor & Increase human peripheral blood lymphocytes, enhanced production of TNF-a, NO & [109] \\
\hline FIP-vvo & Volvariella volvacea & Enhance expression of IL-2, IL-4, IFN-g, TNF-a & [110] \\
\hline
\end{tabular}




\subsection{Terpenes and Terpenoids}

Terpenes are a large and diverse class of hydrocarbon compounds derived biosynthetically from units of isopentenyl pyrophosphate. They are widespread in nature, produced by a variety of plants, particularly conifers, some insects, and fungi, including mushrooms. The addition of functional groups (usually oxygen-containing) to terpenes produce terpenoids. Both terpenes and terpenoids from a number of medicinal mushrooms have shown immunoregulatory activities with medical significance. Table 5 shows the types of terpenes and terpenoids that have been isolated from medicinal mushrooms, including evidence for their specific immunomodulatory activities. For example, Ganoderma sp. are known for their high content of triterpenoids and these triterpenoids have shown high immunomodulating and anti-infective activities [111-113]. A study showed that terpenes and terpenoids modulate immune system functions by stimulating the expressions of genes coding for proteins in the nuclear factor (NF)-kB pathway and for mitogen-activated protein kinases [14]. 
Table 5. Major immunomodulatory terpenes and terpenoids from medicinal mushrooms and their immunomodulatory effects.

\begin{tabular}{|c|c|c|c|c|}
\hline $\begin{array}{c}\text { Type of } \\
\text { Terpenes }\end{array}$ & Source & Compound & Immunomodulatory Effect & Refs \\
\hline Monoterpenoids & Pleurotus cornucopiae & - & Inhibit the proliferation of HeLa and HepG2 cells & [114] \\
\hline \multirow{6}{*}{ Sesquiterpenoids } & Stereum hirsutum & - & Inhibit the proliferation of HepG2 and A549 cells & [111] \\
\hline & Inonotus rickii & $3 \alpha, 6 \alpha-$ Hydroxycinnamolide & Inhibit the proliferation of SW480 cells & [112] \\
\hline & Pleurotus cornucopiae & Pleurospiroketals A, B, C & Inhibit the proliferation of HeLa cells & [113] \\
\hline & Anthracophyllum sp. BCC18695 & Anthracophyllone & $\begin{array}{l}\text { Inhibit the proliferation of MCF7, NCI-H187, KB } \\
\text { and Vero cells }\end{array}$ & [115] \\
\hline & Flammulina velutipes & $\begin{array}{c}\text { Enokipodins B, D, J } \\
\text { 2,5-cuparadiene-1,4-dione } \\
\text { Flammulinolides A, B, C, F }\end{array}$ & $\begin{array}{l}\text { Inhibit the proliferation of HepG2, MCF7, } \\
\text { SGC7901, KB, HeLa and A549 cells }\end{array}$ & {$[116,117]$} \\
\hline & Neonothopanus nambi & Nambinones C & Inhibit the proliferation of NCI-H187 cells & [118] \\
\hline \multirow{4}{*}{ Diterpenoids } & Cyathus africanus & $\begin{array}{c}\text { Neosarcodonin } \mathrm{O}, \\
\text { 11-O-acetylcyathatriol, Cyathins } \mathrm{H}\end{array}$ & Inhibit the proliferation of K562 and Hela cells & [119] \\
\hline & Pleurotus eryngii & Eryngiolide A & Inhibit the proliferation of Hela and HepG2 cells & [120] \\
\hline & Sarcodon scabrosus & Sarcodonin G & $\begin{array}{l}\text { Inhibit the proliferation of HOC-21, HEC-1, } \\
\text { U251-SP, MM-1CB and HMV-1 cells }\end{array}$ & [121] \\
\hline & Tricholoma sp. & Tricholomalide A, B, C & Inhibit the proliferation of HeLa cells & [122] \\
\hline
\end{tabular}


Table 5. Cont

\begin{tabular}{|c|c|c|c|c|}
\hline $\begin{array}{c}\text { Type of } \\
\text { Terpenes }\end{array}$ & Source & Compound & Immunomodulatory Effect & Refs \\
\hline \multirow{12}{*}{ Triterpenoids } & Ganoderma boninense & Ganoboninketals A, B, C & Inhibit the proliferation of A549 and HeLa cells & [123] \\
\hline & Ganoderma orbiforme BCC 22324 & Ganoderic acid T and its C-3 epimer compound & Inhibit the proliferation of NCIH187, MCF7 and KB cells & [124] \\
\hline & Ganoderma lucidum & $\begin{array}{l}\text { lucialdehydes } B, C \text {, ganodermanondiol, } \\
\text { ganodermanonol, ganoderic acid DM, ganoderic acid X }\end{array}$ & $\begin{array}{c}\text { Inhibit the proliferation of T-47D, LLC, Meth-A, } \\
\text { and Sarcoma } 180 \text { cells; Decrease the protein levels of } \\
\text { CDK2, CDK6, p-Rb, cycle D1 and c-Myc in MCF7 cells; } \\
\text { inhibit activity against topoisomerases I and II } \alpha \text { and } \\
\text { promote apoptosis }\end{array}$ & [125-127] \\
\hline & Ganoderma concinna & $\begin{array}{c}5 \alpha \text {-lanosta-7,9(11),24-triene-3 } \beta \text {-hydroxy-26-al, } \\
5 \alpha \text {-lanosta-7,9(11),24-triene-15 } \alpha \text {-26-dihydroxy-3-one, } \\
8 \alpha, 9 \alpha \text {-epoxy-4,4,14 } \alpha \text {-trimethyl-3,7,11,15,20- } \\
\text { pentaoxo-5 } \alpha \text {-pregrane }\end{array}$ & Induce apoptosis in promyelocyticleukemia HL-60 cells & [128] \\
\hline & Ganoderma tsugae & $\begin{array}{l}\text { Tsugaric acid A, } 3 \beta \text {-hydroxy- } 5 \alpha \text {-lanosta- } 8 \\
\text { 24-dien-21-oic acid }\end{array}$ & Inhibit the proliferation of HT-3, T-24, and CaSKi cells & [129] \\
\hline & $\begin{array}{c}\text { Hypholoma fasciculare } \\
\text { (syn. Naematoloma fasciculare) }\end{array}$ & Fusciculol C, L, M, G & $\begin{array}{l}\text { Inhibit the proliferation of HCT-15, SK-OV-3, SK-MEL-2 } \\
\text { and A549 cells }\end{array}$ & [130] \\
\hline & Astraeus odoratus & Astraodoric acids A, B, D & $\begin{array}{l}\text { Inhibit the proliferation of KB, NCI-H187, } \\
\text { and MCF7 cells }\end{array}$ & [131] \\
\hline & Russula lepida Russula amarissima & Cucurbitane hydroxyl acid & Inhibit the proliferation of WISH, CAKI 1 and A549 cells & [132] \\
\hline & Leucopaxillus gentianeus & $\begin{array}{c}\text { Cucurbitacin B } \\
\text { Leucopaxillone A }\end{array}$ & $\begin{array}{l}\text { Inhibit the proliferation of MCF7, HepG2, kidney } \\
\text { carcinoma CAKI-1 and A549 cells }\end{array}$ & [133] \\
\hline & Hebeloma versipelle & 24(E)-3ß-hydroxylanosta-8,24-dien-26-al-21-oic acid & $\begin{array}{l}\text { Inhibit the proliferation of HL60, Bel-7402, SGC-7901 } \\
\text { and A549 cells }\end{array}$ & [134] \\
\hline & Tricholoma saponaceum & Saponaceol A & Inhibit the proliferation of HL-60 cells & [135] \\
\hline & Elfvingia applanata & The methyl ester of elfvingic acid $\mathrm{H}$ & Inhibit the proliferation of Ehlrich and Kato III cells & [136] \\
\hline
\end{tabular}




\section{Immunomodulation and Other Human Health Effects of Medicinal Mushrooms}

The human immune system is tightly linked to tumor development. With the increasing impact of tumor on human health, a large number of studies have been undertaken to identify mushroom extracts/fractions/compounds with antitumor activities. Indeed, some of the observed antitumor activities by medicinal mushroom extracts were based on the activation of the immune system (Tables 2-5). Davis et al. (2020) recently suggested that 17 medicinal mushroom species (A. brazei, Cordyceps militaris, Flammulina velutipe, F. fomentarius, F. officinalis, Ganoderma applanatum, G. lucidum, Ganoderma oregonense, G. frondosa, Hericium erinaceus (syn. Hericium erinaceum), I. obliquus, L. edodes, Tropicoporus linteus (syn. Phellinus linteus), P. betulinus, Pleurotus ostreatus, S. commune) could support both immune-activation for cancer treatments and help resolve host defense-induced inflammatory reactions and facilitate a post-response return to homeostasis for cancer patients. Furthermore, a medicinal mushroom formulation consisting of G. lucidum, L. edodes and G. frondosa showed synergistic antitumor and immuno-modulatory activity in human macrophages [137].

As shown in Tables 2-5, many medicinal mushrooms each can produce different categories of compounds with immunomodulatory effects. Furthermore, different extractions of the same mushroom may show non-overlapping but complementary activities. For example, in L. edodes, its heterogalactan (fucomannogalactan) has anti-inflammatory properties [138], lentinan has anti-tumor effect [139], crude water-soluble polysaccharides can activate macrophages and increase the productions of nitric oxide (NO), cytokines, and proteins related to phagocytosis [140], and polysaccharides with both antioxidant effects [141] and antiviral activities [142].

The significance of functional components from medicinal mushrooms has been shown not only from clinical perspectives but also from foods. Because many medicinal mushrooms are commercially cultivated for food, there has been an increasing trend of including mushrooms and their components into other foods to develop functional foods, including adding new flavors or promoting certain types of functions. For example, Ulziijargal et al. used mushroom mycelia of T. camphoratus, A. blazei, H. erinaceus, and P. linteus to substitute $5 \%$ of wheat flour to make bread. The final product contains substantial amounts of the amino acids gaminobutyric acid (GABA) and ergothioneine and showed beneficial health effects [143]. Kim et al. developed noodles that contained L. edodes paste, resulting in a higher quality, fibre-rich functional food with antioxidant and hypocholesterolemic properties [144]. Components of other mushrooms, e.g., Pleurotus sajor-caju dry powder, A. bisporus extracts, the freeze-dried powder from A. aegerita, Suillus luteus, and Coprinopsis atramentaria have been used to develop snacks and cheese-related products with much commercial success [145-148]. The benefits include increased proteins, minerals, crude fiber or ingredients with antioxidant potentials and free radical scavenging capacities. The diversified flavors and tastes as well as the enhanced nutritional values of food due to the addition of mushroom components represent an exciting direction for the edible and medicinal mushroom industries.

\section{Mechanisms for the Immunomodulation Effects of Medicinal Mushroom Compounds}

The immune system consists of a network of cells, tissues and organs that work together to defend the body against attacks by "foreign" invaders [2]. The network is connected by lymphatic vessels from organ to organ. The network includes protective barriers that constantly communicate with lymphatic fluid rich in white blood cells and leukocytes. When pathogens break our physical barriers (i.e., skin and mucosal membranes of the mouth, nose, the gastrointestinal tract, and the urogenital tract), the next line of the body's defense response is activated. This line of defense includes granulocytes and monocytes that also function as antigen-presenting cells (APCs) for helper T lymphocytes. These cells synthetize and secrete lipid mediators such as prostaglandins as well as cytokines which act as messengers in regulating immune response and stimulating adaptive immunity. For example, natural killer (NK) cells can recognize infected and abnormal cells, such as cancer cells and kill these cells by inducing them to undergo apoptosis or by producing cytokines, such as interferon-gamma (IFN- $\gamma$ ). They also 
activate macrophages and kill phagocytosed microbes. Figure 3 presents the overview of the key immune response against microbial pathogens.

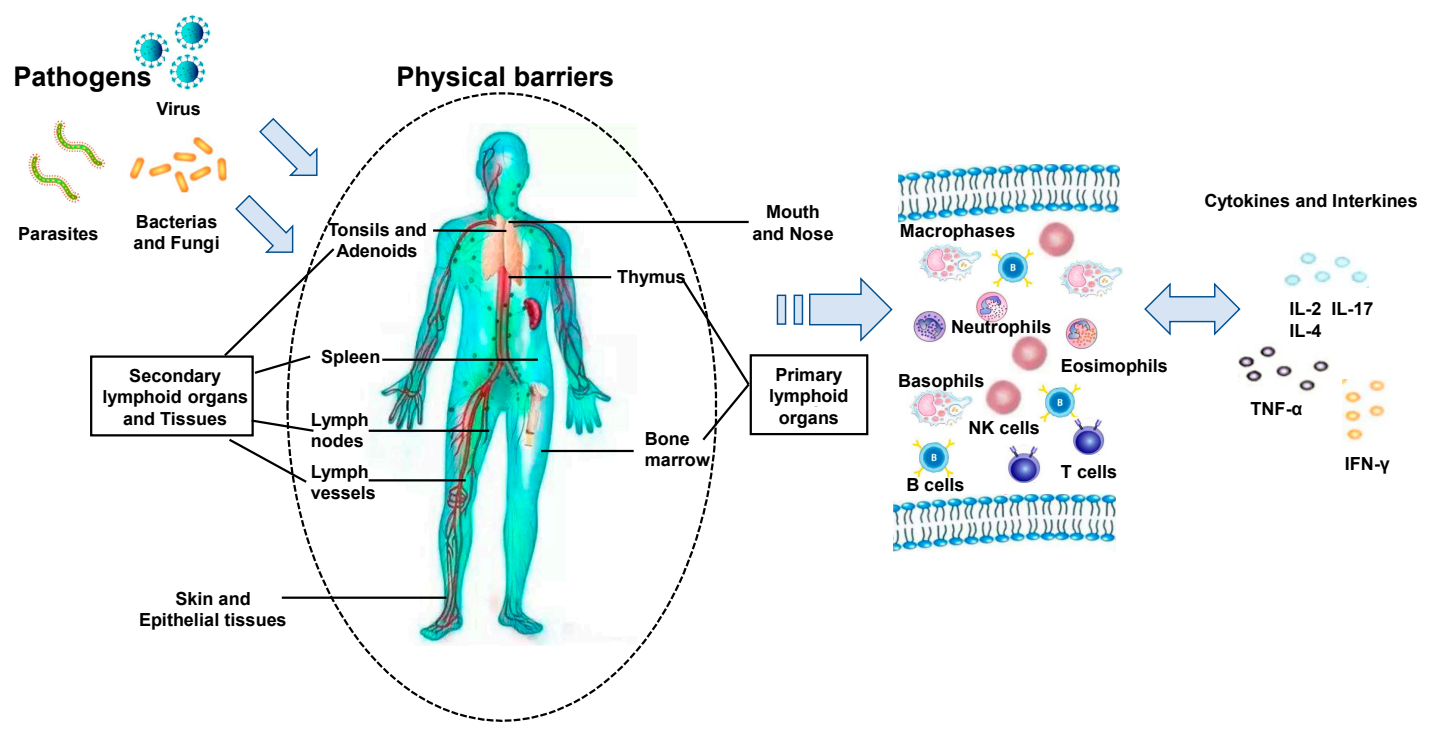

Figure 3. Key components and pathways in host immune response against pathogen infections.

It is well known that the human immune system can be modulated by foods, supplements or endogenous bioactive agents [2]. Different types of immunoregulatory compounds have been isolated from medicinal mushrooms, including mushroom fruiting bodies and fermented mycelia. Tables 2-5 present the specific components isolated from different mushroom species that have shown significant immunomodulatory activities, including their (potential) mechanisms of action. For example, two polysaccharides from two different mushroom species have shown significant immunoenhancing activities. In the first, a glucuronoxylomannan TAP-3 obtained from Naematelia aurantialba (syn. Tremella aurantialba) showed marked immune enhancement activity and promoted NO, IL-1 $\beta$ and TNF- $\alpha$ secretions from macrophages [149]. Similarly, another study showed that at a concentration of $40 \mu \mathrm{g} / \mathrm{mL}$, polysaccharide CCP from Craterellus cornucopioides strengthened the phagocytic function of macrophages, increased the expression of cytokines, upregulated the expression of cell membrane receptor TLR4 and downstream protein kinase products through activation of the TLR4-NFKB pathway [150].

Some of these bioactive compounds can also directly attack cancer cells while showing immunoregulatory effects. For example, Li et al. reported that polysaccharide LRP-1 purified from Leccinum rugosiceps inhibited the growth of human hepatoma cells HepG2 and human breast carcinoma MCF-7 cells, and induced the secretion of NO, IL-6 and TNF- $\alpha$ in vitro [151]. Similarly, a recent report showed that an aqueous extract of Sarcodon imbricatus (SIE) effectively inhibited the growth, migration, and invasion properties of breast cancer cells in vitro and reduced tumor growth in vivo, while showing increased expression of PD-L1 and increased NK cell viability [152]. Furthermore, Xue et al. reported that a triterpenoid EAe from Pleurotus eryngii inhibited MCF-7 cell lines proliferation with an EC50 of $298.26 \mu \mathrm{g} / \mathrm{mL}$, and significantly inhibited the growth of CD-1 tumors (inhibition rate of 65\%) in mice in a dose-dependent manner without toxicity [153].

\section{Relationship between Structure and Activity of Immunomodulatory Compounds from Medicinal Mushrooms}

Immunomodulators from medicinal mushrooms have been shown to be capable of stimulating both innate and adaptive immune responses. They activate innate immune system components such as natural killer (NK) cells, neutrophils, and macrophages, and stimulate the expression and secretion of cytokines. These cytokines in turn activate adaptive immunity by promoting B cell proliferation and 
differentiation for antibody production and by stimulating $\mathrm{T}$ cell differentiation to $\mathrm{T}$ helper (Th) 1 and Th2 cells, which mediate cellular and humoral immunities, respectively [154].

As shown in Tables 2-5, a large number of immunoregulatory compounds from medicinal mushrooms have been reported. These compounds differ greatly in their molecular weight and structure. Below we describe the relationships between their molecular structures and immunoregulatory activities.

\subsection{Polysaccharides}

Polysaccharides are the most commonly reported natural immunomodulators from mushrooms. The immunomodulating polysaccharides are highly diversified in their sugar compositions, main chain polymer structures, degrees of branching, conformations, molecular weights, and other physical properties, which together have significant effects on the bioactivity and mode of action of each polysaccharide [18]. These polysaccharides are either homoglycans (polysaccharides that contain residues of only one type of monosaccharide molecule) or heteroglycans (polysaccharides that contain residues of two or more types of monosaccharide molecules), and are able to combine with other molecules such as oligo- or poly-peptides to make peptidoglycan or polysaccharide-protein complexes. In general, higher molecular weight polysaccharides exhibit greater bioactivity [155]. These large polysaccharides are not able to penetrate the immune cells, but instead act to bind cell receptors. For example, the highest immunomodulatory activity of PSK was associated with the highest molecular weight fraction of this compound, at $>200 \mathrm{kDa}$ [156]. Similarly, the highest activity of a polysaccharide fraction of G. frondosa extract was ascribed to one with a molecule weight of over $800 \mathrm{kDa}$ [157]. In contrast, low molecular weight polysaccharides can penetrate immune cells and exert stimulatory effects from within.

The number and lengths of short branched chains in mushroom polysaccharides can significantly influence their bioactivity [155]. In most cases, the bioactive immunomodulator polysaccharides are characterized by a main chain of $1,3-\beta$-D-glucan with a small number of short branched chains with $1,6-\beta$-linkage (Figure 4). Studies have shown that immunologically active polysaccharides generally have a degree of branching number (DB) between $20 \%$ and $40 \%$. For example, lentinan has a DB number of $40 \%$, schizophyllan of $33 \%$, and PSK of $20 \%$. While a high DB number is generally correlated with a high activity, in some cases, debranching of polysaccharides can also increase their bioactivity. For example, the partially debranched form of pachymaran from Poria cocos showed greater activity than the original native form [158]. Even in the well-studied lentinan, its maximal immunomodulating and antitumor activities were achieved when the molecule had a DB of 32\% [159], and there was a negative correlation between their biological activity and DB number between 32 and 40\% [160].
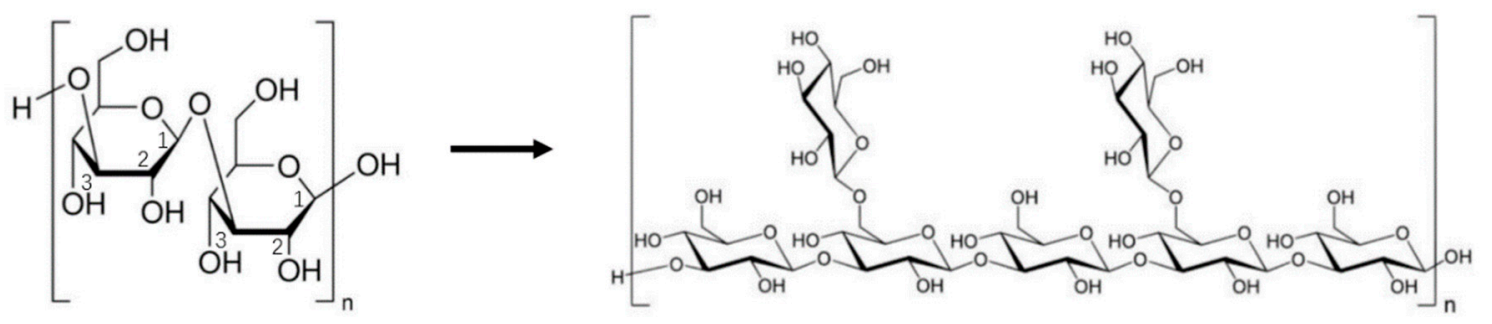

Figure 4. The basic structures of bioactive polysaccharides 1-3,- $\beta$-D-glucan and short branched chains with 1-6,- $\beta$-linkage.

Aside from the main-chain structure and branching pattern, the conformation of polysaccharides can also impact their bioactivity, e.g., by influencing the stability of the structure. In polysaccharides, the triple helix conformation is usually more stable than other conformations and bears the cytokine stimulating activity of the $\beta$-D-glucan. Lentinan, schizophyllan, scleroglucan, and PSK all have a triple helix structure [161]. However, not all polysaccharide immunomodulators from mushrooms have the 
triple helix structure. For example, mushroom polysaccharides with a random coil conformation can also have potent immunomodulating and anticancer activity [56].

Chemical modification is an effective and common approach to increase biological activities of polysaccharides. This approach has been applied to develop a number of effective immunomodulators from mushroom polysaccharides. Those modifications include carboxymethylation, hydroxylation, formyl-methylation, amino-ethylation, or sulfation. The introduction of such chemical groups may increase the possible contacts between the modified polysaccharides and the immune cell receptors through hydrogen bonding and/or electrostatic attraction, and thus increase the immunological response. For example, the sulfated cell wall glucan from L. edodes exhibited higher immunomodulatory and anticancer activities compared to the native polysaccharides [162]. The increased effect from sulfation may be related to the increased solubility, as shown in the hyper branched $\beta$-glucan TM3b. Taken together, molecular weight, branching, chemical configuration, and chemical modification can all have strong influence on the bioactivity of polysaccharides from mushrooms.

\subsection{Lectins}

Lectins belong to a unique group of proteins that can recognize and interact with various cell surface carbohydrates/glycoproteins. Mushroom lectins have shown specific immunomodulatory, antiproliferative, and antitumor activities [163]. The diverse sources of mushroom lectins have different immunomodulatory mechanisms: some mediate their actions by activating the immune system while others produce potent cytotoxic effects towards cells [91]. For example, two lectins extracted from L. mongolica (syn.T. mongolicum), TML-1 and TML-2, show immunomodulatory and antitumor activities. These two lectins stimulate the production of nitrite and tumor necrosis factor (TNF)- $\alpha$ and inhibit the growth of mouse lymphoblast-like (p815) mastocytoma cells by the production of macrophage-activating factors. These factors include interferon (IFN)- $\gamma$ and other cytokines, activated through upregulation of inducible nitric oxide synthase (NOS), interleukin (IL)- $1 \beta$, and transforming growth factor- $\beta$ [91]. G. frondosa lectin is reported as having a potent cytotoxic effect against HeLa cells in vitro, even at very low concentrations. A 15.9-kDa homodimeric, lactose-binding, ricin-B-like lectin (CNL) from Clitocybe nebularis exhibited antiproliferative activity against human leukemic $\mathrm{T}$ cells [78], which induces the maturation and activation of dendritic cells (DCs) and stimulates several proinflammatory cytokines such as IL-6, IL-8, and TNF- $\alpha$ [164]. The encoding gene of CNL from C. nebularis has been cloned and successfully expressed in Escherichia coli [165].

\subsection{FIPs}

The fungal immunomodulatory proteins are a group of proteins with highly similar amino acid sequences. They exist as dimers in a dumbbell-shaped structure similar to that of the variable region of immunoglobulin heavy chains [166]. The FIPs have shown diverse functions. Through binding to Toll-like receptors (TLRs), FIPs stimulate antigen presenting cells and release cytokines such as $\mathrm{NO}$ and IL-12. By activating phosphorylation of p38/MAPK and increasing the production of NF- $\mathrm{kB}$, FIPs can promote the proliferation and differentiation of helper T cells (Th0) to form Th1 cells and Th2 cells, activate macrophages and B cells, produce a variety of cell factors (Figure 5). For example, FIP-fve from Flammulina velutipes can upregulate the expression of intercellular adhesion molecules on the T cell surface by phosphorylation of p38/MAPK, and activate Th1 cells to produce IL-2, IFN- $\gamma$, to exert its immunomodulatory effect [99]. FIP-vvo can not only activate Th1 cells and enhance IL-2, TNF- $\alpha$ and IFN- $\gamma$ transformations, but also induce Th 2 cells to produce IL-4, B cell differentiation, and the transformation of immunoglobulin and production of antibody IgE. Several studies have also shown that by interacting with TLRs, FIP can activate other signaling pathways besides the p38/MAPK and NF-k B. For example, FIP from Ganoderma tsugae (FIP-gts) can stimulate human peripheral blood monocyte to produce IFN- $\gamma$ and activates the PI3K/Akt signaling pathway [104]. 


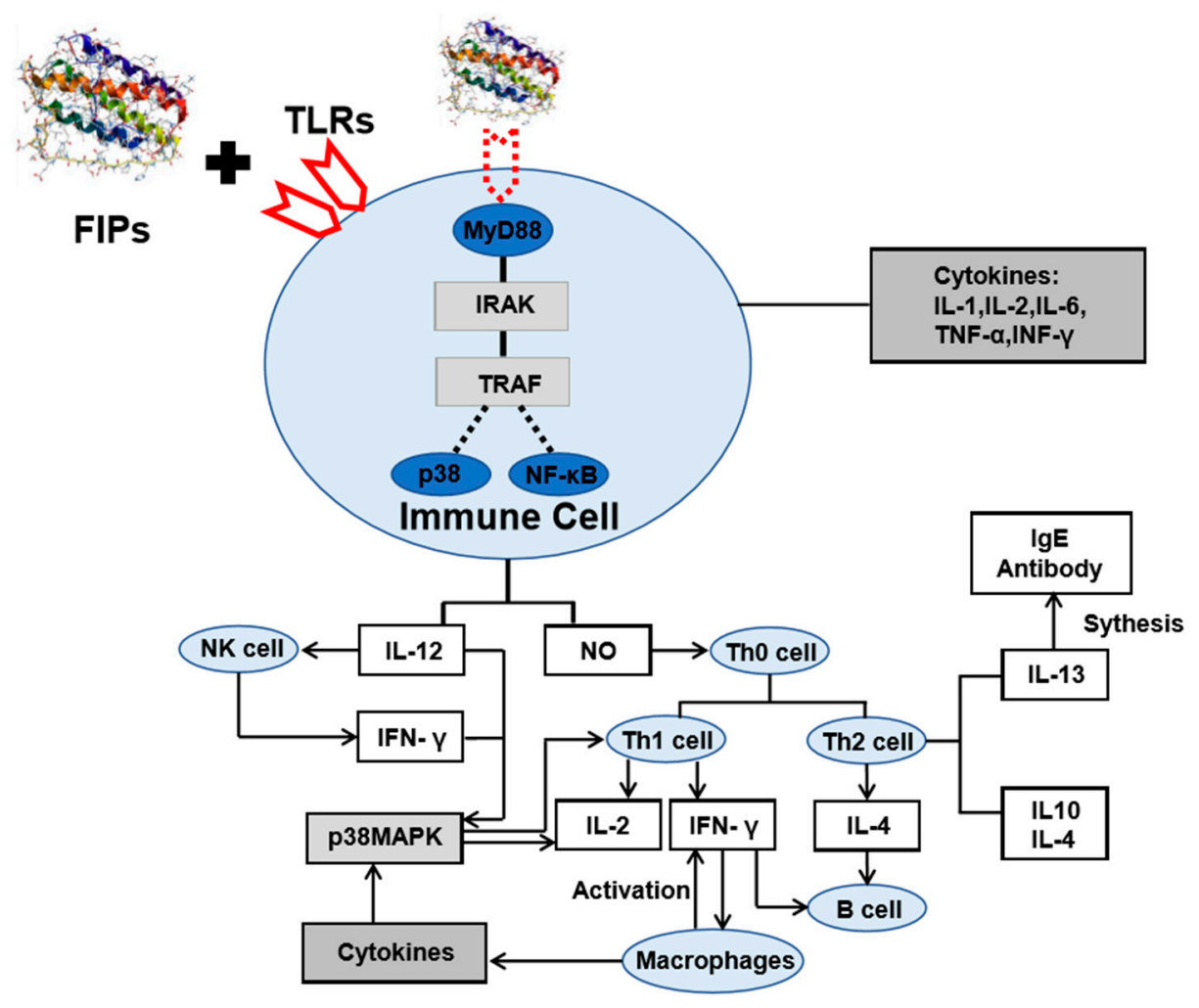

Figure 5. FIPs immunomodulatory mechanism by toll-like receptors (TLRs) signaling pathway.

FIPs typically exist in low quantities in their native mushrooms. The low yield/production has been a major limitation of their research and application. Therefore, techniques are being rapidly developed to enhance the production of recombinant FIPs in other organisms such as the yeast Pichia pastoris and the bacterium E. coli. For example, the LZ-8 gene of G. lucidum has been expressed in P. pastoris to produce a recombinant LZ-8 protein (rLZ-8). While the recombinant protein lacks the carbohydrate moiety of the native protein, it shows similar bioactivity for IL-2 induction as the native protein. The FIP-fve protein has also been successfully expressed in E. coli [1]. Interestingly, the recombinant FIPs showed higher immunomodulatory activity and induced greater expression of specific cytokines than that extracted from the mushrooms [167].

\subsection{Terpenes and Terpenoids}

Terpenes and terpenoids are widely distributed in mushrooms. They are a large and diversified group of organic compounds but share the core of isoprene five-carbon atom units of molecular formula $\left(\mathrm{C}_{5} \mathrm{H}_{6}\right) \mathrm{n}$ as the main building block (Figure 6) [1,13]. Among this group of compounds, the best-known is probably the triterpenoids from G. lucidum and G. lingzhi. These triterpenoids can help reduce drug nephrotoxicity and minimize inflammation. Figure 6 shows a diversity of terpene derivatives in G. lucidum and G. lingzhi, including ganodermic and ganoderic acids, ganoderals, ganoderols, ganodermanontriol, lucidone, and ganodermanondiol. All these compounds have shown immunomodulating, antitumor, and/or anti-infective activities [168]. At present, their mechanisms of action and structure-activity relationships are little understood. However, their broad activities suggest significant potential for research and for clinical therapeutic applications. 


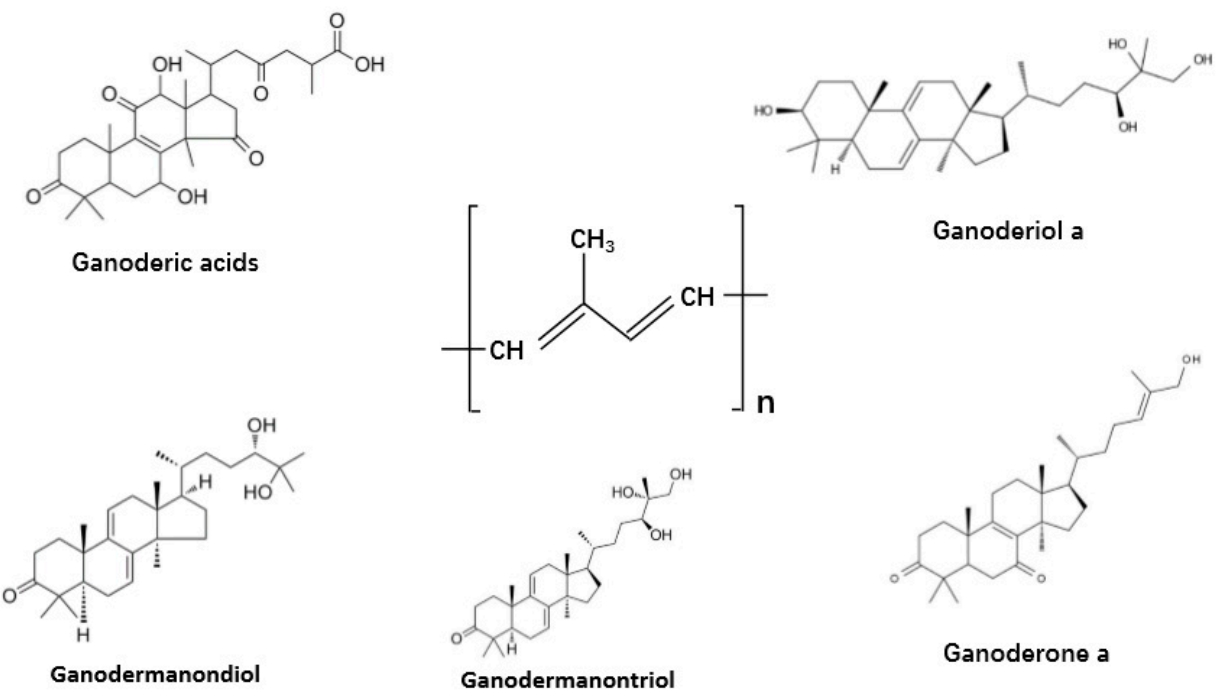

Figure 6. The structures of representative terpenes and terpenoids in the fungus Ganoderma lucidum and Ganoderma lingzhi.

\section{Genomes and Molecular Techniques in the Study of Immunomodulatory Compounds in Medicinal Mushrooms}

Due to their environmental, agricultural, commercial, and/or medical interests, the genomes of a number of medicinal mushrooms have been sequenced and annotated. Table 6 lists the genomic features of 12 representative medicinal mushrooms. These species differ in genome size and/or gene content. Analyses of these genomes have revealed some of the genes related to the synthesis and production of immunomodulatory compounds in medicinal mushrooms. Not surprisingly, the most commonly identified genes related to immunomodulatory effects are those coding for FIPs (Table 6). However, in G. lucidum, genes involved in the synthesis of several other immunomodulators have also been identified. The identification and confirmation of those genes require genetic manipulation systems which are not available at present for most medicinal mushrooms. In G. lucidum, such a system is available.

Ganoderic acids (GAs) are among the main active ingredients of G. lucidum with immunomodulatory effects. GAs belong to the triterpenoid secondary metabolites. Genome sequence analyses and functional studies showed that the terpenoids in G. lucidum are synthesized through the Mevalonate (MVA) pathway. Several genes in this pathway in G. lucidum have been cloned and their functional roles confirmed, including those encoding 3-Hydroxy-3-methylglutaryl-CoA reductase (HMGR) and Farnesyl diphosphate synthase (FPPs). Genome sequence data mining also identified the putative genes involved in the modification of the triterpene backbone, such as those involved in cyclization and glycosylation, which are very important for the synthesis of the diversity of GAs in G. lucidum.

At present, most of the genes and metabolic pathways involved in the synthesis of immunomodulators in the categories of polysaccharides, lectins, and terpenoids in medicinal mushrooms have not been identified or confirmed. However, the availability of increasing genomic resources coupled with the broad pharmacological activities and therapeutic effects of medicinal mushrooms should help facilitate the identification of genes and metabolic pathways involved in their biosynthesis. Such understandings could help future productions of those compounds through biotechnology using surrogate hosts. 
Table 6. Major genomic features of representative medicinal mushrooms.

\begin{tabular}{|c|c|c|c|c|c|c|}
\hline Medicinal Mushroom & $\begin{array}{l}\text { Genome Size } \\
\mathrm{Mb}\end{array}$ & $\begin{array}{l}\text { Number of } \\
\text { Genes }\end{array}$ & $\begin{array}{c}\text { GC } \\
\text { Content }(\%)\end{array}$ & $\begin{array}{l}\text { Known Genes Related to Immunomodulatory } \\
\text { Effects }\end{array}$ & $\begin{array}{l}\text { Genetic Manipulations } \\
\text { (Transformation Method) }\end{array}$ & Refs \\
\hline Agrocybe aegerita & 44.7908 & 14110 & 49.2 & & $\begin{array}{l}\text { Polyethylene glycol-mediated } \\
\text { transformation (PEG) }\end{array}$ & [169] \\
\hline Agaricus bisporus & 30.78 & 10863 & 46.5 & & $\begin{array}{c}\text { PEG, Electroporation, Particle } \\
\text { bombardment, Agrobacterium } \\
\text { tumefaciens-mediated transformation } \\
\text { (ATMT) }\end{array}$ & [170-173] \\
\hline Flammulina velutipes & 35.64 & & 49.76 & Fip-fve & $\begin{array}{l}\text { PEG, Electroporation, Electro-injection, } \\
\text { Restriction enzyme-mediated } \\
\text { integration (REMI), ATMT }\end{array}$ & [173-177] \\
\hline Ganoderma atrum & & & & fip-gat & & [178] \\
\hline Ganoderma lucidum & 43.68 & & 55.4 & $\begin{array}{c}\text { fip-glu, Mevalonate (MVA) pathway genes: } A A C T \\
\text { (acetyl-CoA acetyltransferase); HMGS } \\
\text { (3-hydroxy-3-methylglutaryl-CoA synthase), HMGR } \\
\text { (3-hydroxy-3-methylglutaryl-CoA reductase), MVK } \\
\text { (mevalonate kinase), MPK (phosphomevalonate } \\
\text { kinase), MVD (pyrophosphomevalonate } \\
\text { decarboxylase), IDI (isopentenyl-diphosphate } \\
\text { isomerase), GPPS (geranyl diphosphate synthase), } \\
\text { FPPs (farnesyl diphosphate synthase), SQS (squalene } \\
\text { synthase), SE (squalene monooxygenase), OSC } \\
\text { (2,3-oxidosqualene-lanosterol cyclase), P450 } \\
\text { (cytochrome P450), UGTS (uridine diphosphate } \\
\text { glycosyltransferases) }\end{array}$ & PEG, Electroporation, REMI & {$[173,179-181]$} \\
\hline Ganoderma sinensis & 48.96 & 15478 & 55.6 & fip-gsi & & {$[103,182]$} \\
\hline Ganoderma tsugae & 45.5 & & & fip-gts & & [183] \\
\hline $\begin{array}{c}\text { Hericium erinaceus } \\
\text { (syn. Hericium erinaceum) }\end{array}$ & 41.21 & & 52.43 & & ATMT & {$[184,185]$} \\
\hline Lentinula edodes & 39.92 & 12051 & 46 & & PEG, Electro-injection, REMI, ATMT & {$[173,186]$} \\
\hline Pleurotus ostreatus & 34.36 & 12296 & 50.76 & & $\begin{array}{l}\text { PEG, Electroporation, REMI, Particle } \\
\text { bombardment }\end{array}$ & {$[173,187-189]$} \\
\hline Postia placenta & 66.6724 & 12716 & 47.2 & fip-ppl & & {$[108,190]$} \\
\hline Trametes versicolor & 44.794 & 14572 & 57.3 & fip-tvc & & {$[191,192]$} \\
\hline Volvariella volvacea & 35.72 & & 48.8 & fip-vvo & PEG, Particle bombardment, ATMT & {$[193,194]$} \\
\hline
\end{tabular}




\section{Conclusions and Perspectives}

Many edible and medicinal mushrooms contain compounds with significant immunoregulatory activities. This paper attempts to provide a comprehensive review on the types of these compounds; their distributions, structures and functions; and their potential mechanisms of actions. These compounds have shown their activities through in vitro, ex vivo, tissue cultures, and/or in vivo studies. Some of these compounds have been commercialized and licensed for clinical use.

Aside from the above described compounds, other compounds from edible and medicinal mushrooms may also have great potentials. One such group is chitin and chitin-related compounds. Chitin is the most common aminopolysaccharide polymer in nature and the main material that gives strength to the fungal cell walls (as well as to the exoskeletons of crustaceans and insects). Through deacetylation, either chemically or enzymatically, chitin can be converted to chitosan, a well-known derivative. Through hydrolysis, both chitin and chitosan can be converted to chito-oligosaccharides. Several fungal chitin, chitosan, and chito-oligosaccharides have shown promising benefits to humans and human health $[195,196]$. For example, chitins from filamentous molds such as Aspergillus niger and Mucor rouxii and other organisms have been used in plant protection and food processing; chitosan in diagnosis, drug delivery, infection control, molecular imaging, and wound healing; and chito-oligosaccharides in antimicrobial and antitumor activities $[195,196]$. At present, none of those tested chitin, chitosan, and chito-oligosaccharides for human effects have come from edible or medicinal mushrooms yet. However, due to the similar chemical structures of chitin from different groups of organisms, it's highly likely that this group of natural products from edible and medicinal mushrooms will have similar effects and they represent a promising area of future development for edible and medicinal mushrooms.

While the future looks bright, significant issues remain before the full potential of medicinal mushrooms can be reached. Specifically, during our review of the literature, we identified several significant gaps and areas for future research and development. In the first, there is an urgent need to identify the structures and mechanisms of action for active ingredients in many extracts and formulations from medicinal mushrooms. More rigorous chemical analyses as well as understanding the in vivo pharmacokinetics and pharmacodynamics of individual compounds are needed to fill this gap of knowledge. The second promising area of study is to identify the genes and metabolic pathways involved in producing these immunomodulators in medicinal mushrooms. As shown above, aside from the few FIPs where the specific encoding genes have been identified, we have little information about the genes and how they are regulated in producing the other types of mushroom immunomodulators. While the availability of high through-put technologies and genome sequences are facilitating the discoveries, experimental investigations are needed in order to confirm and identify the conditions for increased productions of these compounds. Fortunately, gene editing technologies and -omics tools are becoming increasingly accessible to the broader life sciences communities. In the third, most immunomodulators described above exist in low quantities in medicinal mushrooms and their extractions can take a long time and be costly. For efficient production, it is very important to develop alternative approaches, e.g., by cloning and expressing the relevant biosynthesis genes in alternative hosts, using industrial fermentations, and developing efficient extraction and purification protocols from such commercial cell cultures. Lastly, the potential interactions between immunomodulators from mushrooms and other medicines, foods, and food supplements need to be critically analyzed in order to establish guidelines for safe and effective use of immunomodulators from medicinal mushrooms [197]. Indeed, at present, safety data about many medicinal mushroom products are not available from controlled clinical trials and associated negative side effects have been reported in several cases for certain types of usages of medicinal mushroom products [198,199]. There is also a cultural difference between Oriental and Western cultures about the use of medicinal mushrooms [197], presenting both a challenge and an opportunity for researchers and policy makers on the broad implications of these products on human health. 
Author Contributions: S.Z. and J.X. conceived and prepared the manuscript, Q.G., C.R. and Z.Z. participated in the manuscript editing; S.W. and Y.L. provided the photos of mushrooms. All authors have read and agreed to the published vision of manuscript.

Funding: This work was supported by National Natural Science Foundation of China (NSFC31701975), by the Collaborative Innovation Center of Beijing Academy of Agricultural and Forestry Sciences (KJCX201915), and by Beijing Academy of Agriculture and Forestry Sciences (KJCX20200208).

Acknowledgments: We thank Junliang Zhou from Kunming University for providing the photos of mushroom species.

Conflicts of Interest: The authors declare no conflict of interest.

\section{References}

1. El Enshasy, H.A.; Hatti-Kaul, R. Mushroom Immunomodulators: Unique Molecules with Unlimited Applications. Trends Biotechnol. 2013, 31, 668-677. [CrossRef] [PubMed]

2. Reis, F.S.; Martins, A.; Vasconcelos, M.H.; Morales, P.; Ferreira, I.C.F.R. Functional Foods Based on Extracts or Compounds Derived from Mushrooms. Trends. Food Sci. Technol. 2017, 66, 48-62. [CrossRef]

3. Himanshi, R.; Shalinee, P.; Satyawati, S. Mushroom nutraceuticals for improved nutrition and better human health: A review. PharmaNutrition 2017, 5, 35-46. [CrossRef]

4. Mannino, G.; Stefano, V.D.; Lauria, A.; Pitonzo, R.; Gentile, C. Vaccinium Macrocarpon (Cranberry)-Based Dietary Supplements: Variation in Mass Uniformity, Proanthocyanidin Dosage and Anthocyanin Profile Demonstrates Quality Control Standard Needed. Nutrients 2020, 12, 992. [CrossRef]

5. Brya, P. Who Reads Food Labels? Selected Predictors of Consumer Interest in Front-of-Package and Back-of-Package Labels during and after the Purchase. Nutrients 2020, 12, 2605. [CrossRef]

6. Shukla, S.; Bajpai, V.K.; Kim, M. Plants as Potential Sources of Natural Immunomodulators. Rev. Environ. Sci. Biol. 2014, 13, 17-33. [CrossRef]

7. Wasser, S.P. Medicinal Mushroom Science: History, Current Status, Future Trends, and Unsolved Problems. Int. J. Med. Mushrooms 2010, 12,1-16. [CrossRef]

8. Davis, R.; Taylor, A.; Nally, R.; Benson, K.F.; Stamets, P.; Jensen, G.S. Differential Immune Activating, Anti-Inflammatory, and Regenerative Properties of the Aqueous, Ethanol, and Solid Fractions of a Medicinal Mushroom Blend. J. Inflamm. Res. 2020, 13, 117-131. [CrossRef]

9. Chilton, J. A New Analytical Fingerprinting Method for Quality Control of Medicinal Mushroom Products. In Proceedings of the 2016 International Society for Mushroom Science, Amsterdam, The Netherlands, 30 May-2 June 2016; Sonnenberg, B., Ed.; International Society for Mushroom Science (ISMS): Amsterdam, The Netherlands, 2016; pp. 267-270.

10. Dubey, S.K.; Chaturvedi, V.K.; Mishra, D.; Bajpeyee, A.; Tiwari, A.; Singh, M.P. Role of Edible Mushroom as A Potent Therapeutics for the Diabetes and Obesity. 3 Biotech 2019, 9. [CrossRef]

11. Chaturvedi, V.K.; Agarwal, S.; Gupta, K.K.; Ramteke, P.W.; Singh, M.P. Medicinal Mushroom: Boon for Therapeutic Applications. 3 Biotech 2018, 8. [CrossRef]

12. Wong, J.H.; Ng, T.B.; Chan, H.H.L.; Liu, Q.; Man, G.C.W.; Zhang, C.Z.; Guan, S.; Ng, C.C.W.; Fang, E.F.; Wang, H.; et al. Mushroom Extracts and Compounds with Suppressive Action on Breast Cancer: Evidence from Studies Using Cultured Cancer Cells, Tumor-Bearing Animals, and Clinical Trials. Appl. Microbiol. Biotechnol. 2020, 104, 4675-4703. [CrossRef]

13. Moradali, M.F.; Mostafavi, H.; Ghods, S.; Hedjaroude, G.A. Immunomodulating and Anticancer Agents in the Realm of Macromycetes Fungi (Macrofungi). Int. Immunopharmacol. 2007, 7, 701-724. [CrossRef]

14. Gao, Y.H.; Zhou, S.F.; Chen, G.L.; Dai, X.H.; Ye, J.X. A Phase I/II Study of a Ganoderma lucidum (Curt.: Fr.) P. Karst. Extract (Ganopofy) in Patients with Advanced Cancer. Int. J. Med. Mushrooms 2002, 4, $207-214$. [CrossRef]

15. Lee, J.S.; Cho, J.Y.; Hong, E.K. Study on Macrophage Activation and Structural Characteristics of Purified Polysaccharides from the Liquid Culture Broth of Hericium erinaceus. Carbohydr. Polym. 2009, 78, 162-168. [CrossRef]

16. Riede, I. Tumor Therapy with Amanita phalloides (Death Cap): Stabilization of B-Cell Chronic Lymphatic Leukemia. J. Altern. Complement. Med. 2010, 16, 1129-1132. [CrossRef] 
17. Van, G.; Leo, J.L.D. Culinary-Medicinal Mushrooms: Must Action Be Taken? Int. J. Med. Mushrooms 2009, 11, 281-286. [CrossRef]

18. Chakraborty, I.; Sen, I.K. Bioactive Polysaccharides from Natural Sources: A review on the Antitumor and Immunomodulating Activities. Biocatal. Agric. Biotechnol. 2019, 22, 101425. [CrossRef]

19. Ina, K.; Kataoka, T.; Ando, T. The Use of Lentinan for Treating Gastric Cancer. Anti-Cancer Agent Med. Chem. 2013, 13, 681-688. [CrossRef]

20. Ngwuluka, N.C.; Ochekpe, N.A.; Aruoma, O.I. Functions of Bioactive and Intelligent Natural Polymers in the Optimization of Drug Delivery. In Industrial Applications for Intelligent Polymers and Coatings; Springer International Publishing: New York, NY, USA, 2016; pp. 165-184. [CrossRef]

21. Cui, J.; Chisti, Y. Polysaccharopeptides of Coriolus versicolor: Physiological Activity, Uses, and Production. J. Shanxi Med. Univ. 2003, 21, 109-122. [CrossRef]

22. Oba, K.; Teramukai, S.; Kobayashi, M.; Matsui, T.; Kodera, Y.; Sakamoto, J. Efficacy of Adjuvant Immunochemotherapy with Polysaccharide K for Patients with Curative Resections of Gastric Cancer. Cancer Immunol. Immun. 2007, 56, 905-911. [CrossRef] [PubMed]

23. Hattori, T.S.; Komatsu, N.; Shichijo, S.; Itoh, K. Protein-Bound Polysaccharide K Induced Apoptosis of the Human Burkitt Lymphoma Cell Line, Namalwa. Biomed. Pharm. 2004, 58, 226-230. [CrossRef] [PubMed]

24. Kato, M.; Hirose, K.; Hakozaki, M.; Ohno, M.; Saito, Y.; Izutani, R.; Noguchi, J.; Hori, Y.; Okumoto, S.; Kuroda, D. Induction of Gene Expression for Immunomodulating Cytokines in Peripheral Blood Mononuclear Cells in Response to Orally Administered PSK, An Immunomodulating Protein-bound Polysaccharide. Cancer Immunol. Immun. 1995, 40, 152-156. [CrossRef] [PubMed]

25. Price, L.A.; Wenner, C.A.; Sloper, D.T.; Slaton, J.W.; Novack, J.P. Role for Toll-like Receptor 4 in TNF-alpha Secretion by Murine Macrophages in Response to Polysaccharide Krestin, a Trametes versicolor mushroom extract. Fitoterapia 2010, 81, 914-919. [CrossRef]

26. Kidd, P.M. The Use of Mushroom Glucans and Proteoglycans in Cancer Treatment. Altern. Med. Rev. 2000, 5 , $4-27$.

27. Ooi, V.E.C. Pharmacological Studies on Certain Mushrooms from China. Int. J. Med. Mushrooms $2001,3,1$. [CrossRef]

28. Biedron, R.; Tangen, J.M.; Maresz, K.; Hetland, G. Agaricus blazei Murill-Immunomodulatory Properties and Health Benefits. Funct. Foods Health Dis. 2012, 2, 428-447. [CrossRef]

29. Firenzuoli, F.; Gori, L.; Lombardo, G. The Medicinal Mushroom Agaricus blazei Murrill: Review of Literature and Pharmaco-Toxicological Problems. Evid.-Based Complement. Altern. Med. 2008, 5, 3-15. [CrossRef]

30. Ma, Z.; Wang, J.; Zhang, L.; Zhang, Y.; Ding, K. Evaluation of Water Soluble $\beta$-d-glucan from Auricularia auricular-judae as Potential Anti-tumor Agent. Carbohydr. Polym. 2010, 80, 977-983. [CrossRef]

31. Pacheco-Sanchez, M.; Boutin, Y.; Angers, P.; Gosselin, A.; Tweddell, R.J. A Bioactive (1 -> 3)-, (1 -> 4)-beta-D-glucan from Collybia dryophila and Other Mushrooms. Mycologia 2006, 98, 180-185. [CrossRef]

32. Chen, P.X. Properties of Cordyceps sinensis: A Review. J. Funct. Foods 2013, 5, 550-569. [CrossRef]

33. Yao, H.Y.; Zhang, L.H.; Shen, J.; Shen, H.J.; Jia, Y.L.; Yan, X.F.; Xie, Q.M. Cyptoporus Polysaccharide Prevents Lipopolysaccharide-Induced Acute Lung Injury Associated with Down-regulating Toll-like Receptor 2 Expression. J. Ethnopharmacol. 2011, 137, 1267-1274. [CrossRef] [PubMed]

34. Yin, H.; Wang, Y.; Wang, Y.; Chen, T.; Tang, H.; Wang, M. Purification, Characterization and Immuno-Modulating Properties of Polysaccharides Isolated from Flammulina velutipes Mycelium. Am. J. Chin. Med. 2010, 38, 191-204. [CrossRef]

35. Zhu, X.L.; Chen, A.F.; Lin, Z.B. Ganoderma lucidum Polysaccharides Enhance the Function of Immunological Effector Cells in Immunosuppressed Mice. J. Ethnopharmacol. 2007, 111, 219-226. [CrossRef]

36. Matsui, K.; Kodama, N.; Nanba, H. Effects of Maitake (Grifola frondosa) D-Fraction on the Carcinoma Angiogenesis. Cancer Lett. 2001, 172, 193-198. [CrossRef]

37. Dong, P.W.; Lee, J.S.; Kwon, D.S.; Lee, K.E.; Shin, W.C.; Hong, E.K. Immunostimulating Activity by Polysaccharides Isolated from Fruiting Body of Inonotus obliquus. Mol. Cells 2011, 31, 165-173. [CrossRef]

38. Mizuno, T. The Extraction and Development of Antitumor-Active Polysaccharides from Medicinal Mushrooms in Japan (Review). Int. J. Med. Mushrooms 1999, 1, 9-29. [CrossRef]

39. Bisen, P.S.; Baghel, R.K.; Sanodiya, B.S.; Thakur, G.S.; Prasad, G.B.K.S. Lentinus edodes: A Macrofungus with Pharmacological Activities. Curr. Med. Chem. 2010, 17, 2419-2430. [CrossRef] 
40. Morales, D.; Rutckeviski, R.; Villalva, M.; Abreu, H.; Smiderle, F.R. Isolation and Comparison of $\alpha$ - and $\beta$-D-glucans from Shiitake Mushrooms (Lentinula edodes) with Different Biological Activities. Carbohydr. Polym. 2019, 229, 115521. [CrossRef] [PubMed]

41. Bhunia, S.K.; Dey, B.; Maity, K.K.; Patra, S.; Mandal, S.; Maiti, S.; Maiti, T.K.; Sikdar, S.R.; Islam, S.S. Isolation and Characterization of an Immunoenhancing Glucan from Alkaline Extract of an Edible mushroom, Lentinus squarrosulus (Mont.) Singer. Carbohyd. Res. 2011, 346, 2039-2044. [CrossRef]

42. Cui, H.L.; Chen, Y.; Wang, S.S.; Kai, G.Q.; Fang, Y.M. Isolation, Partial Characterisation and Immunomodulatory Activities of Polysaccharide from Morchella esculenta. J. Sci. Food Agric. 2011, 91, 2180-2185. [CrossRef]

43. Su, C.A.; Xu, X.Y.; Liu, D.Y.; Ming, W. Isolation and Characterization of Exopolysaccharide with Immunomodulatory Activity from Fermentation Broth of Morchella conica. DARU J. Pharm. Sci. 2013, 21, 5. [CrossRef]

44. Du, X.; Zhang, J.; Yang, Y.; Tang, Q.; Jia, W.; Pan, Y. Purification, Chemical Modification and Immunostimulating Activity of Polysaccharides from Tremella aurantialba Fruit Bodies. J. Zhejiang Univ. Sci. B 2010. [CrossRef]

45. Roy, S.K.; Das, D.; Mondal, S.; Maiti, D.; Bhunia, B.; Maiti, T.K.; Islam, S.S. Structural Studies of an Immunoenhancing Water-soluble Glucan Isolated from Hot Water Extract of an Edible Mushroom, Pleurotus florida, Cultivar Assam Florida. Carbohyd. Res. 2009, 344, 2596-2601. [CrossRef] [PubMed]

46. Dey, B.; Bhunia, S.K.; Maity, K.K.; Patra, S.; Mandal, S.; Maiti, S.; Maiti, T.K.; Sikdar, S.R.; Islam, S.S. Glucans of Pleurotus florida Blue variant: Isolation, Purification, Characterization and Immunological Studies. Int. J. Biol. Macromol. 2012, 50, 591-597. [CrossRef] [PubMed]

47. Gern, R.M.M.; Wisbeck, E.; Rampinelli, J.R.; Ninow, J.L.; Furlan, S.A. Alternative Medium for Production of Pleurotus ostreatus Biomass and Potential Antitumor Polysaccharides. Bioresour. Technol. 2008, 99, 76-82. [CrossRef]

48. Chen, X.; Xu, X.; Zhang, L.; Kennedy, J.F. Flexible Chain Conformation of $(1 \rightarrow 3)$ - $\beta$-d-glucan from Poria cocos sclerotium in $\mathrm{NaOH} /$ urea Aqueous Solution. Carbohyd. Polym. 2009, 75, 586-591. [CrossRef]

49. Lin, Y.; Zhang, L.; Chen, L.; Jin, Y.; Zeng, F.; Jin, J.; Wan, B.; Cheung, P.C.K. Molecular Mass and Mntitumor Activities of Sulfated Derivatives of $\alpha$-glucan from Poria cocos Mycelia. Int. J. Biol. Macromol. 2004, 34, 231-236. [CrossRef]

50. Han, X.Q.; Wu, X.M.; Chai, X.Y.; Chen, D.; Dai, H.; Dong, H.L.; Ma, Z.Z.; Gao, X.M.; Tu, P.F. Isolation, Characterization and Immunological Activity of a Polysaccharide from the Fruit Bodies of an Edible Mushroom, Sarcodon aspratus (Berk.) S. Ito. Food Res. Int. 2011, 44, 489-493. [CrossRef]

51. Hobbs, C. The Chemistry, Nutritional Value, Immunopharmacology, and Safety of the Traditional Food of Medicinal Split-Gill Fugus Schizophyllum commune Fr.:Fr. (Schizophyllaceae). A Literature Review. Int. J. Med. Mushrooms 2005, 7, 127-140. [CrossRef]

52. Bimczok, D.; Wrenger, J.; Schirrmann, T.; Rothkotter, H.J.; Wray, V.; Rau, U. Short Chain Regioselectively Hydrolyzed Scleroglucans Induce Maturation of Porcine Dendritic Cells. Appl. Microbiol. Biotechnol. 2009, 82, 321-331. [CrossRef]

53. Liu, J.J.; Huang, T.S.; Hsu, M.L.; Chen, C.C.; Lin, W.S.; Lu, F.J.; Chang, W.H. Antitumor Effects of the Partially Purified Polysaccharides from Antrodia camphorata and the Mechanism of Its Action. Toxicol. Appl. Pharm. 2004, 201, 186-193. [CrossRef]

54. Wu, S.J.; Liaw, C.C.; Pan, S.Z.; Yang, H.C.; Ng, L.T. Phellinus linteus Polysaccharides and Their Immunomodulatory Properties in Human Monocytic Cells. J. Funct. Foods 2013, 5, 679-688. [CrossRef]

55. Rau, U.; Kuenz, A.; Wray, V.; Nimtz, M.; Wrenger, J.; Cicek, H. Production and Structural Analysis of the Polysaccharide Secreted by Trametes (Coriolus) versicolor ATCC 200801. Appl. Microbiol. Biotechnol. 2009, 81, 827-837. [CrossRef]

56. Wasser, S. Medicinal Mushrooms as a source of Antitumor and Immunomodulating Polysaccharides. Appl. Microbiol. Biotechnol. 2002, 60, 258-274. [CrossRef]

57. Baets, S.D.; Vandamme, E.J. Extracellular Tremella polysaccharides: Structure, properties and applications. Biotechnol. Lett. 2001, 23, 1361-1366. [CrossRef]

58. Ko, H.J.; Song, A.; Lai, M.N.; Ng, L.T. Immunomodulatory Properties of Xylaria nigripes in Peritoneal Macrophage Cells of Balb/c Mice. J. Ethnopharmacol. 2011, 138, 762-768. [CrossRef] [PubMed] 
59. Li, Y.R.; Liu, Q.H.; Wang, H.X.; Ng, T.B. A Novel Lectin with Potent Antitumor, Mitogenic and HIV-1 Reverse Transcriptase Inhibitory Activities from the Edible Mushroom Pleurotus citrinopileatus. Biochim. Biophys. Acta (BBA)-Gen. Subj. 2008, 1780, 51-57. [CrossRef]

60. Zhao, J.K.; Wang, H.X.; Ng, T.B. Purification and Characterization of a Novel Lectin from the Toxic Wild Mushroom Inocybe umbrinella. Toxicon 2009, 53, 360-366. [CrossRef]

61. Zhang, G.Q.; Sun, J.; Wang, H.X.; Ng, T.B. A Novel Lectin with Antiproliferative Activity from the Medicinal Mushroom Pholiota adiposa. Acta. Biochim. Pol. 2009, 56, 415-421. [CrossRef]

62. Ngai, P.H.K.; Ng, T.B. A Mushroom (Ganoderma capense) Lectin with Spectacular Thermostability, Potent Mitogenic Activity on Splenocytes, and Antiproliferative Activity toward Tumor Cells. Biochem. Biophys. Res. Commun. 2004, 314, 988-993. [CrossRef]

63. Han, C.H.; Liu, Q.H.; Ng, T.B.; Wang, H.X. A Novel Homodimeric Lactose-binding Lectin from the Edible Split Gill Medicinal Mushroom Schizophyllum commune. Biochem. Biophys. Res. Commun. 2005, 336, 252-257. [CrossRef]

64. Zhao, S.; Zhao, Y.; Li, S.; Zhao, J.; Zhang, G.; Wang, H.; Ng, T.B. A Novel Lectin with Highly Potent Antiproliferative and HIV-1 Reverse Transcriptase Inhibitory Activities from the Edible Wild Mushroom Russula delica. Glycoconj. J. 2010, 27, 259-265. [CrossRef]

65. Licastro, F.; Morini, M.C.; Kretz, O.; Dirheimer, G.; Creppy, E.E.; Stirpe, F. Mitogenic Activity and Immunological Properties of Bolesatine, A Lectin Isolated from the Mushroom Boletus satanas Lenz. Int. J. Biochem. 1993, 25, 789. [CrossRef]

66. Ho, J.C.K.; Sze, S.C.W.; Shen, W.Z.; Liu, W.K. Mitogenic Activity of Edible Mushroom Lectins. Biochim. Biophys. Acta (BBA)-Gen. Subj. 2004, 1671, 9-17. [CrossRef] [PubMed]

67. Silvana, A.; Paola, M.; Cerdeiras, M.; Fraguas, L.F. Screening for Lectins from Basidiomycetes and Isolation of Punctularia atropurpurascens Lectin. J. Basic Microbiol. 2014, 54, 89-96. [CrossRef]

68. Amano, K.; Katayama, H.; Saito, A.; Ando, A.; Nagata, Y.; Yoshiho, N. Aleuria aurantia Lectin Exhibits Antifungal Activity Against Mucor racemosus. Biosci. Biotechnol. Biochem. 2012, 76, 967-970. [CrossRef]

69. Rana, T.; Bera, A.K.; Das, S.; Bhattacharya, D.; Pan, D.; Bandyopadhyay, S.; Mondal, D.K.; Samanta, S.; Bandyopadhyay, S.; Das, S.K. Pleurotus florida Lectin Normalizes Duration Dependent Hepatic oxidative Stress Responses Caused by Arsenic in Rat. Exp. Toxicol. Pathol. 2012. [CrossRef] [PubMed]

70. Zhang, G.Q.; Chen, Q.J.; Hua, J.; Liu, Z.L.; Sun, Y.; Xu, X.; Han, P.; Wang, H.X. An Inulin-Specific Lectin with Anti-HIV-1 Reverse Transcriptase, Antiproliferative, and Mitogenic Activities from the Edible Mushroom Agaricus bitorquis. BioMed Res. Int. 2019, 2019, 1341370. [CrossRef]

71. Yu, L.G.; Fernig, D.G.; Smith, J.A.; Milton, J.D.; Rhodes, J.M. Reversible Inhibition of Proliferation of Epithelial Cell Lines by Agaricus bisporus (Edible Mushroom) Lectin. Cancer Res. 1993, 53, 4627-4632. [CrossRef]

72. Yang, Q.; Yin, Y.; Pan, Y.; Ye, X.; Xu, B.; Yu, W.; Zeng, H.; Sun, H. Anti-metastatic Activity of Agrocybe aegerita Galectin (AAL) in a Mouse Model of Breast Cancer Lung Metastasis. J. Func. Foods 2018, 41, 163-170. [CrossRef]

73. Zhao, C.; Sun, H.; Tong, X.; Qi, Y. An Antitumour Lectin from the Edible Mushroom Agrocybe aegerita. Biochem. J. 2003, 374, 321-327. [CrossRef]

74. Lutsik-Kordovsky, M.D.; Stasyk, T.V.; Stoika, R.S. Analysis of Cytotoxicity of Lectin and Non-lectin Proteins from Amanita Mushrooms. Exp. Oncol. 2001, 23, 43-45.

75. Feng, K.; Liu, Q.H.; Ng, T.B.; Liu, H.Z.; Li, J.Q.; Chen, G.; Sheng, H.Y.; Xie, Z.L.; Wang, H.X. Isolation and Characterization of a Novel Lectin from the Mushroom Armillaria luteo-virens. Biochem. Biolphys. Res. Commun. 2006, 345, 1573-1578. [CrossRef] [PubMed]

76. Zheng, S.; Li, C.; Ng, T.B.; Wang, H.X. A Lectin with Mitogenic Activity from the Edible wild Mushroom Boletus edulis. Process Biochem. 2007, 42, 1620-1624. [CrossRef]

77. Sun, J.; Ng, T.B.; Wang, H.X.; Zhang, G.Q. A Novel Hemagglutinin with Antiproliferative Activity against Tumor Cells from the Hallucinogenic Mushroom Boletus speciosus. BioMed Res. Int. 2014, 2014, 340467. [CrossRef]

78. Pohleven, J.; Obermajer, N.A.; Saboti, J.A.; Lovar, S.; Sep, I.K.; Kos, J.; Kralj, B.; Trukelj, B.; Brzin, J.E. Purification, Characterization and Cloning of a Ricin B-like Lectin from Mushroom Clitocybe nebularis with Antiproliferative Activity Against Human Leukemic T cells. Biochim. Biophys. Acta (BBA)-Gen. Subj. 2009, 1790, 173-181. [CrossRef] [PubMed] 
79. Ng, T.B.; Ngai, P.H.K.; Xia, L. An Agglutinin with Mitogenic and Antiproliferative Activities from the Mushroom Flammulina velutipes. Mycologia 2006, 98, 167-171. [CrossRef]

80. Kawagishi, H.; Nomura, A.; Mizuno, T.; Kimura, A.; Chiba, S. Isolation and Characterization of a Lectin from Grifola frondosa Fruiting Bodies. Biochim. Biophys. Acta (BBA)-Gen. Subj. 1990, 1034, 247-252. [CrossRef]

81. Li, Y.; Zhang, G.; Ng, T.B.; Wang, H. A Novel Lectin with Antiproliferative and HIV-1 Reverse Transcriptase Inhibitory Activities from Dried Fruiting Bodies of the Monkey Head Mushroom Hericium erinaceum. J. Biomed. Biotechnol. 2010, 2010, 716515. [CrossRef]

82. Koyama, Y.; Katsuno, Y.; Miyoshi, N.; Hayakawa, S.; Mita, T.; Muto, H.; Isemura, S.; Aoyagi, Y.; Isemura, M. Apoptosis Induction by Lectin Isolated from the Mushroom Boletopsis leucomelas in U937 Cells. Biosci. Biotechnol. Biochem. 2002. [CrossRef]

83. Wu, Y.; Wang, H.; Ng, T.B. Purification and Characterization of a Lectin with Antiproliferative Activity toward Cancer Cells from the Dried Fruit Bodies of Lactarius flavidulus. Carbohyd. Res. 2011, 346, 2576-2581. [CrossRef]

84. Pushparajah, V.; Fatima, A.; Chong, C.H.; Gambule, T.Z.; Chan, C.J.; Ng, S.T.; Tan, C.S.; Fung, S.Y.; Lee, S.S.; Tan, N.H. Characterisation of a New Fungal Immunomodulatory Protein from Tiger Milk mushroom, Lignosus rhinocerotis. Sci. Rep. 2016, 6, 30010. [CrossRef] [PubMed]

85. Cordara, G.; Winter, H.C.; Goldstein, I.J.; Krengel, U.; Sandvig, K. The Fungal Chimerolectin MOA Inhibits Protein and DNA Synthesis in NIH/3T3 Cells and May Induce BAX-mediated Apoptosis. Biochem. Biophys. Res. Commun. 2014, 447, 586-589. [CrossRef]

86. Mahajan, R.G.; Patil, S.I.; Mohan, D.R.; Shastry, P. Pleurotus eous Mushroom Lectin (PEL) with Mixed Carbohydrate Inhibition and Antiproliferative Activity on Tumor Cell Lines. J. Biochem. Mol. Biol. Biophys. 2002, 6, 341-345. [CrossRef]

87. Manna, D.; Pust, S.; Torgersen, M.L.; Cordara, G.; Sandvig, K. Polyporus squamosus Lectin La (PSL1a) Exhibits Cytotoxicity in Mammalian Cells by Disruption of Focal Adhesions, Inhibition of Protein Synthesis and Induction of Apoptosis. PLoS ONE 2017, 12, e0170716. [CrossRef]

88. Zhang, G.; Sun, J.; Wang, H.; Ng, T.B. First Isolation and Characterization of a Novel Lectin with Potent Antitumor Activity from a Russula Mushroom. Phytomedicine 2010, 17, 775-781. [CrossRef]

89. Chumkhunthod, P.; Rodtong, S.; Lambert, S.J.; Fordham-Skelton, A.P.; Reynolds, C.D. Purification and Characterization of an N-acetyl-D-galactosamine-specific Lectin from the Edible Mushroom Schizophyllum commune. Biochim. Biophys. Acta (BBA)-Gen. Subj. 2006, 1760, 326-332. [CrossRef]

90. Zhang, W.; Tian, G.; Geng, X.; Zhao, Y.; Tzi, N.; Zhao, L.; Wang, H. Isolation and Characterization of a Novel Lectin from the Edible Mushroom Stropharia rugosoannulata. Molecules 2014, 19, 19880-19891. [CrossRef]

91. Wang, H.X.; Ng, T.B.; Ooi, V.E.C.; Liu, W.K.; Chang, S.T. Actions of Lectins from the Mushroom Tricholoma mongolicum on Macrophages, Splenocytes and Life-span in Sarcoma-bearing Mice. Anticancer Res. 1997, 17, 419-424.

92. Liua, W.K.; Ho, J.C.K.; Ng, T.B. Suppression of Cell Cycle Progression by a Fungal Lectin: Activation of Cyclin-dependent Kinase Inhibitors. Biochem. Pharmacol. 2001, 61, 33-37. [CrossRef]

93. She, Q.B.; Ng, T.B.; Liu, W.K. A Novel Lectin with Potent Immunomodulatory Activity Isolated from Both Fruiting Bodies and Cultured Mycelia of the Edible Mushroom Volvariella volvacea. Biochem. Biophys. Res. Commun. 1998. [CrossRef]

94. Marty-Detraves, C.; Francis, F.; Baricault, L.; Fournier, D.; Paquereau, L. Inhibitory Action of a New lectin from Xerocomus chrysenteron on Cell-substrate Adhesion. Mol. Cell. Biochem. 2004, 258, 49-55. [CrossRef]

95. Liu, Q.; Wang, H.; Ng, T.B. First Report of a Xylose-specific Lectin with Potent Hemagglutinating, Antiproliferative and Anti-mitogenic Activities from a Wild Ascomycete Mushroom. Biochim. Biophys. Acta (BBA)-Gen. Subj. 2006, 1760, 1914-1919. [CrossRef]

96. Sheu, F.; Chien, P.J.; Hsieh, K.Y.; Chin, K.L.; Huang, W.T.; Tsao, C.Y.; Chen, Y.F.; Cheng, H.C.; Chang, H.H. Purification, Cloning, and Functional Characterization of a Novel Immunomodulatory Protein from Antrodia camphorata (Bitter Mushroom) That Exhibits TLR2-Dependent NF-kB Activation and M1 Polarization within Murine Macrophages. J. Agric. Food Chem. 2009, 57, 4130-4141. [CrossRef]

97. Lin, J.W.; Guan, S.Y.; Duan, Z.W.; Shen, Y.H.; Li, T.L. Gene Coning of a Novel Fungal Immunomodulatory Protein from Chroogomphis rutilus and Its Expression in Pichia Pastoris. J. Chem. Technol. Biotechnol. 2016, 91, 2761-2768. [CrossRef] 
98. Li, S.; Jiang, Z.; Sun, L.; Liu, X.; Huang, Y.; Wang, F.; Xin, F. Characterization of a new fungal immunomodulatory protein, FIP-dsq2 from Dichomitus squalens. J. Biol. 2017, 246, 45-51. [CrossRef]

99. Wang, P.H.; Hsu, C.I.; Tang, S.C.; Huang, Y.L.; Lin, J.Y. Fungal Immunomodulatory Protein from Flammulina velutipes Induces Interferon- $\gamma$ Production Through p38 Mitogen-Activated Protein Kinase Signaling Pathway. J. Agric. Food Chem. 2004. [CrossRef]

100. Su, K.Q.; Wang, X.F.; Zhou, X.W. Cloning and Bioinformatics Analysis of Fugal Immunomodulatory Protein Gene from Ganoderma astum. J. Shanghai Jiaotong Univ. 2012, 30, 65-71. (In Chinese)

101. Li, Q.Z.; Wang, X.F.; Bao, T.W.; Liang, R.; Lin, J.; Zhou, X. In Vitro Synthesis of a Recombinant Fungal Immunomodulatory Protein from Lingzhi or Reishi Medicinal Mushroom, Ganoderma lucidum (W.Curt.:Fr.) P.Karst. (Aphyllophoromycetideae) and Analysis of Its Immunomodulatory Activity. Int. J. Med. Mushrooms 2010, 12, 347-358. [CrossRef]

102. Lin, C.H.; Hsiao, Y.M.; Ou, C.C.; Lin, Y.W.; Chiu, Y.L.; Lue, K.H.; Chang, J.G.; Ko, J.L. GMI, a Ganoderma Immunomodulatory Protein, Down-regulates Tumor Necrosis Factor $\alpha$-Induced Expression of Matrix Metalloproteinase 9 via NF-кB Pathway in Human Alveolar Epithelial A549 Cells. J. Agric. Food Chem. 2010, 58, 12014-12021. [CrossRef]

103. Li, Q.; Wang, X.; Chen, Y.; Lin, J.; Zhou, X. Cytokines Expression Induced by Ganoderma sinensis Fungal Immunomodulatory Proteins (FIP-gsi) in Mouse Spleen Cells. Appl. Biochem. Biotechnol. 2010, 162, 1403-1413. [CrossRef]

104. Hsiao, Y.M.; Huang, Y.L.; Tang, S.C.; Shieh, G.J.; Lai, J.Y.; Wang, P.H.; Ying, T.H.; Ko, J.L. Effect of a Fungal Immunomodulatory Protein from Ganoderma tsugae on Cell Cycle and Interferon-gamma Production Through Phosphatidylinositol 3-kinase Signal Pathway. Process Biochem. 2008, 43, 423-430. [CrossRef]

105. Bastiaan-Net, S.; Chanput, W.; Hertz, A.; Zwittink, R.D.; Mes, J.J.; Wichers, H.J. Biochemical and Functional Characterization of Recombinant Fungal Immunomodulatory Proteins (rFIPs). Int. Immunopharmacol. 2013, 15, 167-175. [CrossRef]

106. Cong, W.R.; Xu, H.; Liu, Y.; Li, Q.Z.; Li, W.; Zhou, X.W. Production and Functional Characterization of a Novel Fungal Immunomodulatory Protein FIP-SN15 Shuffled from Two Genes of Ganoderma species. Appl. Microbiol. Biotechnol. 2014, 98, 5967-5975. [CrossRef]

107. Chang, H.H.; Sheu, F. A Novel Fungal Immunomodulatory Protein (PCP) Isolated from Poria cocos Activates Mouse Peritoneal Macrophage Involved in Toll-like Receptor 4. FASEB J. 2007, 21, 702-715. [CrossRef]

108. Li, S.Y.; Shi, L.J.; Ding, Y.; Nie, Y.; Tang, X.M. Identification and Functional Characterization of a Novel Fungal immunomodulatory Protein from Postia placenta. Food Chem. Toxicol. 2015, 78, 64-70. [CrossRef]

109. Feng, L.; Wen, H.A.; Zhang, Y.J.; Min, A.; Liu, X.Z. Purification and Characterization of a Novel Immunomodulatory Protein from the Medicinal Mushroom Trametes versicolor. Sci. China Life Sci. 2011, 54, 91-97. [CrossRef]

110. Hsu, H.Y.; Hua, K.F.; Wu, W.C.; Hsu, J.; Weng, S.T.; Lin, T.L.; Liu, C.Y.; Hseu, R.S.; Huang, C.T. Reishi Immuno-modulation Protein Induces Interleukin-2 Expression via Protein Kinase-dependent Signaling Pathways Within Human T Cells. J. Cell. Physiol. 2008, 215, 15-26. [CrossRef]

111. Ma, K.; Bao, L.; Han, J.; Jin, T.; Yang, X.; Zhao, F.; Li, S.; Song, F.; Liu, M.; Liu, H. New Benzoate Derivatives and Hirsutane Type Sesquiterpenoids with Antimicrobial Activity and Cytotoxicity from the Solid-state Fermented Rice by the Medicinal Mushroom Stereum hirsutum. Food Chem. 2014, 143, 239-245. [CrossRef]

112. Chen, H.P.; Dong, W.B.; Feng, T.; Yin, X.; Li, Z.H.; Dong, Z.J.; Li, Y.; Liu, J.K. Four New Sesquiterpenoids from Fruiting Bodies of the Fungus Inonotus rickii. J. Asian Nat. Prod. Res. 2014, 16, 1-6. [CrossRef]

113. Wang, S.J.; Bao, L.; Han, J.J.; Wang, Q.X.; Yang, X.L.; Wen, H.A.; Guo, L.-D.; Li, S.J.; Zhao, F.; Liu, H.W. Pleurospiroketals A-E, Perhydrobenzannulated 5,5-Spiroketal Sesquiterpenes from the Edible Mushroom Pleurotus cornucopiae. J. Nat. Prod. 2013. [CrossRef] [PubMed]

114. Wang, S.; Bao, L.; Zhao, F.; Wang, Q.; Li, S.; Ren, J.; Li, L.; Wen, H.; Guo, L.; Liu, H. Isolation, Identification, and Bioactivity of Monoterpenoids and Sesquiterpenoids from the Mycelia of Edible Mushroom Pleurotus cornucopiae. J. Agric. Food Chem. 2013, 61, 5122-5129. [CrossRef]

115. Intaraudom, C.; Boonyuen, N.; Supothina, S.; Tobwor, P.; Prabpai, S.; Kongsaeree, P.; Pittayakhajonwut, P. Novel Spiro-sesquiterpene from the Mushroom Anthracophyllum sp. BCC18695. Phytochem. Lett. 2013, 6, 345-349. [CrossRef]

116. Li, L.; Yang, X.; Li, S.; Gao, H.; Yao, X.S.; Wen, H.; Liu, H.W. Bioactive Sesquiterpenoids from the Solid Culture of the Edible Mushroom Flammulina velutipes Growing on Cooked Rice. Food Chem. 2012. [CrossRef] 
117. Wang, Y.; Li, B.; Liu, D.; Yang, X.; Li, S.; Hao, G.; Yao, X.; Wen, H.; Liu, H. Two New Sesquiterpenes and Six Norsesquiterpenes from the Solid Culture of the Edible Mushroom Flammulina velutipes. Tetrahedron 2012, 68, 3012-3018. [CrossRef]

118. Kanokmedhakul, S.; Lekphrom, R.; Kanokmedhakul, K.; Hahnvajanawong, C.; Bua-Art, S.; Saksirirat, W.; Prabpai, S.; Kongsaeree, P. Cytotoxic Sesquiterpenes from Luminescent Mushroom Neonothopanus nambi. Tetrahedron 2012, 68, 8261-8266. [CrossRef]

119. Han, J.J.; Chen, Y.H.; Bao, L.; Yang, X.L.; Liu, D.; Li, S.J.; Zhao, F.; Liu, H. Anti-inflammatory and Cytotoxic Cyathane Diterpenoids from the Medicinal Fungus Cyathus africanus. Fitoterapia 2013, 84, 22-31. [CrossRef]

120. Wang, S.J.; Li, Y.X.; Bao, L.; Han, J.J.; Yang, X.L.; Li, H.R.; Wang, Y.Q.; Li, S.J.; Liu, H.W. Eryngiolide A, a Cytotoxic Macrocyclic Diterpenoid with an Unusual Cyclododecane Core Skeleton Produced by the Edible Mushroom Pleurotus eryngii. Org. Lett. 2012, 14, 3672-3675. [CrossRef] [PubMed]

121. Suzuki. Anti-proliferative and Apoptosis-inducible Activity of Sarcodonin G from Sarcodon scabrosus in HeLa Cells. Int. J. Oncol. 1992. [CrossRef]

122. Tsukamoto, S.; Macabalang, A.D.; Nakatani, K.; Obara, Y.; Ohta, T. Tricholomalides A-C, New Neurotrophic Diterpenes from the Mushroom Tricholoma sp. J. Nat. Prod. 2004, 66, 1578-1581. [CrossRef]

123. Ma, K.; Ren, J.; Han, J.; Bao, L.; Liu, H. Ganoboninketals A-C, Antiplasmodial 3,4-seco-27-Norlanostane Triterpenes from Ganoderma boninense Pat. J. Nat. Prod. 2014, 77, 1847-1852. [CrossRef] [PubMed]

124. Isaka, M.; Chinthanom, P.; Kongthong, S.; Srichomthong, K.; Choeyklin, R. Lanostane Triterpenes from Cultures of the Basidiomycete Ganoderma orbiforme BCC 22324. Phytochemistry 2013. [CrossRef] [PubMed]

125. Gao, J.J.; Min, B.S.; Ahn, E.M.; Nakamura, N.; Lee, H.K.; Hattori, M. New Triterpene Aldehydes, Lucialdehydes A-C, from Ganoderma lucidum and Their Cytotoxicity against Murine and Human Tumor Cells. J. ChemInform. 2002. [CrossRef]

126. Wu, G.S.; Lu, J.J.; Guo, J.J.; Li, Y.B.; Tan, W.; Dang, Y.Y.; Zhong, Z.F.; Xu, Z.T.; Chen, X.P.; Wang, Y.T. Ganoderic Acid DM, a Natural Triterpenoid, Induces DNA Damage, G1 Cell Cycle Arrest and Apoptosis in Human Breast Cancer Cells. Fitoterapia 2012, 83, 408-414. [CrossRef] [PubMed]

127. Li, C.H.; Chen, P.Y.; Chang, U.M.; Kan, L.S.; Fang, W.H.; Tsai, K.S.; Lin, S.B. Ganoderic Acid X, a lanostanoid Triterpene, Inhibits Topoisomerases and Induces Apoptosis of Cancer Cells. Life Sci. 2005, 77, 252-265. [CrossRef]

128. Lez, A.G.G.; León, F.; Rivera, A.; Lez-Plata, J.G.; Padron, J.I. New Lanostanoids from the Fungus Ganoderma concinna. J. Nat. Prod. 2002, 65, 417-421. [CrossRef]

129. Su, H.J.; Fann, Y.F.; Chung, M.I.; Won, S.J.; Lin, C.N. New Lanostanoids of Ganoderma tsugae. J. Nat. Prod. 2000, 63, 514-516. [CrossRef]

130. Kim, K.H.; Moon, E.; Sang, U.C.; Sun, Y.K.; Kang, R.L. Lanostane Triterpenoids from the Mushroom Naematoloma fasciculare. J. Nat. Prod. 2013, 76, 845. [CrossRef]

131. Arpha, K.; Phosri, C.; Suwannasai, N.; Mongkolthanaruk, W.; Sodngam, S. Astraodoric acids A-D: New Lanostane Triterpenes from Edible Mushroom Astraeus odoratus and Their Anti-Mycobacterium Tuberculosis H37Ra and Cytotoxic Activity. J. Agric. Food Chem. 2012, 60, 9834-9841. [CrossRef]

132. Clericuzio, M.; Cassino, C.; Corana, F.; Vidari, G. Terpenoids from Russula lepida and R. amarissima (Basidiomycota, Russulaceae). Phytochemistry 2012, 84, 154-159. [CrossRef]

133. Clericuzio, M.; Tabasso, S.; Bianco, M.A.; Pratesi, G.; Beretta, G.; Tinelli, S.; Zunino, F.; Vidari, G. Cucurbitane Triterpenes from the Fruiting Bodies and Cultivated Mycelia of Leucopaxillus gentianeus. J. Nat. Prod. 2006, 69, 1796-1799. [CrossRef]

134. Shao, H.J.; Chen, Q.; Fei, W.; Zhang, Y.L.; Luo, D.Q.; Liu, J.K. A New Cytotoxic Lanostane Triterpenoid from the Basidiomycete Hebeloma versipelle. Cheminform 2010, 37, 828-831. [CrossRef]

135. Yoshikawa, K.; Kuroboshi, M.; Ahagon, S.; Arihara, S. Three Novel Crustulinol Esters, Saponaceols A-C, from Tricholoma saponaceum. Chem. Pharm. Bull. 2004. [CrossRef]

136. Yoshikawa, K.; Nishimura, N.; Bando, S.; Arihara, S.; Matsumura, E. New Lanostanoids, Elfvingic Acids A-H, from the Fruit Body of Elfvingia applanata. J. Nat. Prod. 2002. [CrossRef]

137. Mallard, B.; Leach, D.N.; Wohlmuth, H.; Tiralongo, J. Synergistic Immuno-modulatory Activity in Human Macrophages of a Medicinal Mushroom Formulation Consisting of Reishi, Shiitake and Maitake. PLoS ONE 2019, 14. [CrossRef] 
138. Carbonero, E.R.; Gracher, A.H.P.; Komura, D.L.; Marcon, R.; Freitas, C.S.; Baggio, C.H.; Santos, A.R.S.; Torri, G.; Gorin, P.A.J.; Iacomini, M. Lentinus edodes heterogalactan: Antinociceptive and anti-inflammatory effects. Food Chem. 2008, 111, 531-537. [CrossRef]

139. Finimundy, T.C.; Dillon, A.J.P.; Henriques, J.A.P.; Ely, M.R. A Review on General Nutritional Compounds and Pharmacological Properties of the Lentinula edodes. Mushroom. Int. J. Food Sci. Nutr. 2014, 5, 1095-1105. [CrossRef]

140. Lee, H.H.; Lee, J.S.; Cho, J.Y.; Kim, Y.E.; Hong, E.K. Study on Immunostimulating Activity of Macrophage Treated with Purified Polysaccharides from Liquid Culture and Fruiting Body of Lentinus edodes. J. Microbiol. Biotechnol. 2009, 19, 566-572. [CrossRef]

141. Chen, H.; Ju, Y.; Li, J.; Yu, M. Antioxidant activities of polysaccharides from Lentinus edodes and Their Significance for Disease Prevention. Int. J. Biol. Macromol. 2012, 50, 214-218. [CrossRef]

142. Rincao, V.P.; Yamamoto, K.A.; Ricardo, N.M.P.S.; Soares, S.A.; Meirelles, L.D.P.; Nozawa, C.; Linhares, R.E.C. Polysaccharide and Extracts from Lentinula edodes: Structural Features and Antiviral activity. J. Virol. 2012, 9. [CrossRef]

143. Ulziijargal, E.; Yang, J.H.; Lin, L.Y.; Chen, C.P.; Mau, J.L. Quality of Bread Supplemented with Mushroom Mycelia. Food Chem. 2013, 138, 70-76. [CrossRef]

144. Kim, S.Y.; Kang, M.Y.; Kim, M.Y. Quality Characteristics of Noodle Added with Browned Oak Mushroom (Lentinus edodes). Korean J. Food Cook. Sci. 2008, 24, 665-671. (In Korean)

145. Parab, D.N.; Dhalagade, J.R.; Sahoo, A.K.; Ranveer, R.C. Effect of Incorporation of Mushroom (Pleurotus sajor-caju) Powder on Quality Characteristics of Papad (Indian snack food). Int. J. Food Sci. Nutr. 2012, 63, 866-870. [CrossRef]

146. Singla, R.; Ghosh, M.; Ganguli, A. Phenolics and Antioxidant Activity of a Ready-to-eat Snack Food Prepared from the Edible Mushroom (Agaricus bisporous). Food Sci. Nutr. 2009, 39, 227-234. [CrossRef]

147. Margaret, B.; Emma, D.; Tiwari, B.K.; Brennan, C.S. Enrichment of Extruded Snack Products with Coproducts from Chestnut Mushroom (Agrocybe aegerita) Production: Interactions between Dietary Fiber, Physicochemical Characteristics, and Glycemic Load. J. Agric. Food Chem. 2012, 60, 4396-4401.

148. Ribeiro, A.; Ruphuy, G.; Lopes, J.C.; Dias, M.M.; Barros, L.; Barreiro, F.; Ferreira, I.C.F.R. Spray-drying Microencapsulation of Synergistic Antioxidant Mushroom Extracts and Their use as Functional Food Ingredients. Food Chem. 2015, 188, 612-618. [CrossRef]

149. Yuan, Q.; Zhang, X.; Ma, M.; Long, T.; Xiao, C.; Zhang, J.; Liu, J.; Zhao, L. Immunoenhancing Glucuronoxylomannan from Tremella Aurantialba Bandoni et Zang and Its Low-Molecular-Weight Fractions by Radical Depolymerization: Properties, Structures and Effects on Macrophages. Carbohydr. Polym. 2020, 238, 116-184. [CrossRef] [PubMed]

150. Guo, M.; Meng, M.; Zhao, J.; Wang, X.; Wang, C. Immunomodulatory Effects of the Polysaccharide from Craterellus cornucopioides Via Activating the TLR4-NFkappaB Signaling Pathway in Peritoneal Macrophages of BALB/c Mice. Int. J. Biol. Macromol. 2020, 160, 871-879. [CrossRef]

151. Li, Y.; You, L.; Dong, F.; Yao, W.; Chen, J. Structural Characterization, Antiproliferative and Immunoregulatory Activities of a Polysaccharide from Boletus leccinum Rugosiceps. Int. J. Biol. Macromol. 2020, 157, 106-118. [CrossRef]

152. Tan, X.; Chen, W.; Jiao, C.; Liang, H.; Yun, H.; He, C.; Chen, J.; Ma, X.; Xie, Y. Anti-tumor and Immunomodulatory Activity of the Aqueous Extract of Sarcodon imbricatus in Vitro and in Vivo. Food Funct. 2020, 11, 1110-1121. [CrossRef] [PubMed]

153. Zhao, H.X.; Li, J.Z.; Wan, C.Y.; Hua, W.; Xiao, H.K.; Lv, Y.P.; Dong, M.H. Antitumor and Immunomodulatory Activity of Pleurotus Eryngii Extract. J. Food Biochem. 2014, 39, 19-27. [CrossRef]

154. Borchers, A.T.; Krishnamurthy, A.; Keen, C.L.; Meyers, F.J.; Gershwin, M.E. The Immunobiology of Mushrooms. Exp. Biol. Med. 2008, 233, 259-276. [CrossRef] [PubMed]

155. Xin, M.; He, B.L.; Li, X.L. Antitumor Polysaccharides from Mushrooms: A Review on the Structural Characteristics, Antitumor Mechanisms and Immunomodulating Activities. Carbohydr. Res. 2016, 30-41. [CrossRef]

156. Kim, F.; Sakagami, H.; Tanuma, S.I.; Konno, K. Stimulation of Interferon- $\gamma$-induced Human Myelogenous Leukemic Cell Differentiation by High Molecular Weight PSK Subfraction. Anticancer Res. 1990, 10, 55-58. [CrossRef] 
157. Adachi, Y.; Ohno, N.; Ohsawa, M.; Oikawa, S.; Yadomae, T. Change of Biological Activities of (1.RAR.3)-.BETA.-D-glucan from Grifola frondosa upon Molecular Weight Reduction by Heat Treatment. Chem. Pharm. Bull. 1990, 38, 477-481. [CrossRef] [PubMed]

158. Chihara, G.; Hamuro, J.; Maeda, Y.; Arai, Y.; Fukuoka, F. Antitumour Polysaccharide Derived Chemically from Natural Glucan (Pachyman). Nature 1970, 225, 943-944. [CrossRef]

159. Bae, I.Y.; Kim, H.W.; Yoo, H.J.; Kim, E.S.; Lee, S.; Dong, Y.P.; Lee, H.G. Correlation of Branching Structure of Mushroom $\beta$-glucan with its Physiological Activities. Food Res. Int. 2013, 51, 195-200. [CrossRef]

160. Ren, L.; Perera, C.; Hemar, Y. Antitumor Activity of Mushroom Polysaccharides: A Review. Food Funct. 2012, 3, 1118-1130. [CrossRef]

161. Palleschi, A.; Bocchinfuso, G.; Coviello, T.; Alhaique, F. Molecular Dynamics Investigations of the Polysaccharide Scleroglucan: First Study on the Triple Helix Structure. Carbohydr. Res. 2005, 340, 2154-2162. [CrossRef]

162. Zhang, P.; Cheung, P.C.K. Evaluation of Sulfated Lentinus edodes $\alpha-(1 \rightarrow 3)$-D-glucan as a Potential Antitumor Agent. J. Agric. Chem. Soc. Jpn. 2002, 66, 1052-1056. [CrossRef]

163. Singh, R.S.; Walia, A.K.; Kennedy, J.F. Mushroom Lectins in Biomedical Research and Development. Int. J. Boil. Macromol. 2019, 151, 1340-1350. [CrossRef]

164. Švajger, U.; Pohleven, J.; Kos, J.; Štrukelj, B.; Jeras, M. CNL, a Ricin B-like Lectin from Mushroom Clitocybe nebularis, Induces Maturation and Activation of Dendritic Cells via the Toll-like Receptor 4 Pathway. Immunology 2011, 134, 409-418. [CrossRef] [PubMed]

165. Pohleven, J.; Renko, J.; Magister, S.; Smith, S.; Magister, D.F.; Kuenzler, M.; Strukelj, B.; Turk, D.; Kos, J.; Sabotic, J. Bivalent Carbohydrate Binding Is Required for Biological Activity of Clitocybe nebularis Lectin (CNL), the N,N'-Diacetyllactosediamine (GalNAc $\beta 1-4 G l c N A c$, LacdiNAc)-Specific Lectin from Basidiomycete C. nebularis. J. Biol. Chem. 2012, 287, 10602-10612. [CrossRef]

166. Zhang, L.Q.; Zhang, Z.Y.; Wei, Z.X. Fungal Immunomodulatory Proteins: Characteristic, Potential Antitumor Activities and Their Molecular Mechanisms. Drug Discov. Today 2018. [CrossRef]

167. Wang, X.F.; Li, Q.Z.; Bao, T.W.; Cong, W.R.; Song, W.X.; Zhou, X.W. In Vitro Rapid Evolution of Fungal Immunomodulatory Proteins by DNA Family Shuffling. Appl. Microbiol. Biotechnol. 2013, 97, 2455-2465. [CrossRef]

168. Jeong, Y.T.; Yang, B.K.; Jeong, S.C.; Kim, S.M.; Song, C.H. Ganoderma applanatum: A Promising Mushroom for Antitumor and Immunomodulating Activity. Phytother. Res. Ptr. 2008, 22, 614-619. [CrossRef]

169. Tao, N.; Cui, X.H.; Cai, H.M.; Ma, Y.H.; Zhao, Y.C.; Chen, W.M. Establishment of Genetic Transformation System of Agrocybe aegerita Using PEG-Mediated Method. Mycosystema 2020, 39, 1100-1108. [CrossRef]

170. Sonnenberg, A.S.M.; Gao, W.; Lavrijssen, B.; Hendrickx, P.; Visser, R.G.F. A Detailed Analysis of the Recombination Landscape of the Button Mushroom Agaricus bisporus Var. bisporus. Fungal Genet. Biol. 2016, 93, 35-45. [CrossRef]

171. Morin, E.; Kohler, A.; Baker, A.R.; Foulongne-Oriol, M.; Lombard, V.; Nagy, L.G.; Ohm, R.A.; Patyshakuliyeva, A.; Brun, A.; Aerts, A.L.; et al. Genome Sequence of the Button Mushroom Agaricus bisporus Reveals Mechanisms Governing Adaptation to a Humic-rich Ecological Niche (vol 109, pg 17501, 2012). Proc. Natl. Acad. Sci. USA 2013, 110, 4146. [CrossRef]

172. Chen, M.Y.; Liao, J.H.; Guo, Z.J.; Li, H.R.; Lu, Z.H.; Cai, D.F.; Wang, Z.S. The Expression Vector Construction and Transformation of Thermotolerance-related Gene of Agaricus bisporus. Mycosystema 2009, 28, 797-801. (In Chinese)

173. Cheng, K.; Zhu, Z.; Wang, J.; Chen, J.; Bao, D.; Chen, M.; Zhang, J.; Tan, Q. Progress in the Genetic Transformation of Edible Fungi. Acta Edulis Fungi 2012, 19, 92-99. (In Chinese)

174. Kurata, A.; Fukuta, Y.; Mori, M.; Kishimoto, N.; Shirasaka, N. Draft Genome Sequence of the Basidiomycetous Fungus Flammulina velutipes TR19. Genome Announc. 2016, 4, e00505-e00516. [CrossRef]

175. Young-Jin, P.; Hun, B.K.; Seonwook, L.; Changhoon, K.; Hwanseok, R.; Hyungtae, K.; Jeong-Sun, S.; Hae-Ran, P.; Dae-Eun, Y.; Jae-Young, N.; et al. Whole Genome and Global Gene Expression Analyses of the Model Mushroom Flammulina velutipes Reveal a High Capacity for Lignocellulose Degradation. PLoS ONE 2014, 9, e93560. [CrossRef]

176. Hyeokjun, Y.; You, Y.H.; Ju-Ri, W.; Young-Jin, P.; Kong, W.S.; Byoung-Moo, L.; Jong-Guk, K. The Mitochondrial Genome of the White-Rot Fungus Flammulina velutipes. J. Gen. Appl. Microbiol. 2012, 58, 331-337. [CrossRef] 
177. Ko, J.L.; Lin, S.J.; Hsu, C.I.; Kao, C.L.; Lin, J.Y. Molecular Cloning and Expression of a Fungal Immunomodulatory Protein, FIP-fve, from Flammulina velutipes. J. Med. Assoc. 1997, 96, 517-524. [CrossRef]

178. Xu, H.; Kong, Y.Y.; Chen, X.; Guo, M.Y.; Bai, X.H.; Lu, Y.J.; Li, W.; Zhou, X.W. Recombinant FIP-gat, a Fungal Immunomodulatory Protein from Ganoderma atrum, Induces Growth Inhibition and Cell Death in Breast Cancer Cells. J. Agric. Food Chem. 2016, 64, 2690-2698. [CrossRef]

179. Li, Q.Z.; Chang, Y.Z.; He, Z.M.; Chen, L.; Zhou, X.W. Immunomodulatory Activity of Ganoderma lucidum Immunomodulatory Protein Via PI3K/Akt and MAPK Signaling Pathways in RAW264.7 Cells. J. Cell. Physiol. 2019, 234, 23337-23348. [CrossRef]

180. Chen, S.L. Genome Sequence of the Model Medicinal Mushroom Ganoderma lucidum. Nat. Commun. $2012,3$. [CrossRef]

181. Liu, D.; Jing, G.; Dai, W.; Kang, X.; Zhuo, H.; Zhang, H.M.; Wei, L.; Le, L.; Ma, J.; Xia, Z. The Genome of Ganderma lucidum Provide Insights into Triterpense Biosynthesis and Wood Degradation. PLoS ONE 2012. [CrossRef]

182. Zhu, Y.; Xu, J.; Sun, C.; Zhou, S.; Xu, H.; Nelson, D.R.; Qian, J.; Song, J.; Luo, H.; Xiang, L. Chromosome-level Genome Map Provides Insights into Diverse Defense Mechanisms in the Medicinal Fungus Ganoderma sinense. Sci. Rep. 2015, 5, 11087. [CrossRef]

183. Wang, P.H.; Yang, S.F.; Chen, G.D.; Han, C.P.; Chen, S.C.; Lin, L.Y.; Ko, J.L. Human Nonmetastatic Clone 23 Type 1 Gene Suppresses Migration of Cervical Cancer Cells and Enhances the Migration Inhibition of Fungal Immunomodulatory Protein from Ganoderma tsugae. Reprod. Sci. 2007, 14, 475-485. [CrossRef]

184. Gong, W.; Wang, Y.; Xie, C.; Zhou, Y.; Peng, Y. Whole Genome Sequence of an Edible and Medicinal mushroom, Hericium erinaceus (Basidiomycota, Fungi). Genomics 2020, 112. [CrossRef]

185. Liu, L.; Xiao, Z.; Guo, L.; Lin, J.; You, L.; Liao, J. Establishment of Genetic Transformation System of Hericium erinaceus Using PEG Mediated Method. Mycosystema 2014, 33, 121-128. (In Chinese)

186. Gong, W.B.; Li, L.; Zhou, Y.; Bian, Y.B.; Kwan, H.S.; Cheung, M.K.; Xiao, Y. Genetic Dissection of Fruiting Body-related Traits Using Quantitative Trait loci Mapping in Lentinula edodes. Appl. Microbiol. Biotechnol. 2016, 100, 5437-5452. [CrossRef]

187. Qu, J.; Zhao, M.; Tom, H.; Feng, X.; Zhang, J.; Huang, C. Identification and Characterization of Small Noncoding RNAs in Genome Sequences of the Edible Fungus Pleurotus ostreatus. BioMed Res. Int. 2016, 2016, 2503023. [CrossRef]

188. Riley, R.; Salamov, A.A.; Brown, D.W.; Nagy, L.G.; Floudas, D.; Held, B.W.; Levasseur, A.; Lombard, V.; Morin, E.; Otillar, R. Extensive Sampling of Basidiomycete Genomes Demonstrates Inadequacy of the White-Rot/Brown-Rot Paradigm for Wood Decay Fungi. Proc. Natl. Acad. Sci. USA 2014, 111, 9923-9928. [CrossRef]

189. Yong, W.; Zeng, F.; Chau, H.C.; Zhang, Y.; Ching, L.F.C. The Mitochondrial Genome of the Basidiomycete Fungus Pleurotus ostreatus (oyster mushroom). FEMS Microbiol. Lett. 2010. [CrossRef]

190. Martinez, D.; Challacombe, J.; Morgenstern, I.; Hibbett, D.; Schmoll, M.; Kubicek, C.P.; Ferreira, P.; Ruiz-Duenas, F.J.; Martinez, A.T.; Kersten, P.; et al. Genome, Transcriptome, and Secretome Analysis of Wood Decay Fungus Postia placenta Supports Unique Mechanisms of Lignocellulose Conversion. Proc. Natl. Acad. Sci. USA 2009, 106, 1954-1959. [CrossRef]

191. Li, F.; Wen, H.; Liu, X.; Zhou, F.; Chen, G. Gene Cloning and Recombinant Expression of a Novel Fungal Immunomodulatory Protein from Trametes versicolor. Protein Expr. Purif. 2012, 82, 339-344. [CrossRef]

192. Floudas, D.; Binder, M.; Riley, R.; Barry, K.; Blanchette, R.A.; Henrissat, B.T.; Martinez, A. The Paleozoic Origin of Enzymatic Lignin Decomposition Reconstructed from 31 Fungal Genomes. Science 2012, 336, 1715-1719. [CrossRef]

193. Sun, X.; Huang, W.; Xiao, S.; Liang, C.; Zhang, S.; Liu, Z.; Sun, F. Extracellular Expression and Efficient Purification of a Functional Recombinant Volvariella volvacea Immunomodulatory Protein (FIP-vvo) Using Pichia Pastoris System. Protein Expr. Purif. 2014, 94, 95-100. [CrossRef] [PubMed]

194. Bao, D.; Gong, M.; Zheng, H.; Chen, M.; Zhang, L.; Wang, H.; Jiang, J.; Wu, L.; Zhu, Y.; Zhu, G. Sequencing and Comparative Analysis of the Straw Mushroom (Volvariella volvacea) Genome. PLoS ONE 2013, 8, e58294. [CrossRef] [PubMed] 
195. Muzzarelli, R.A.A.; Boudrant, J.; Meyer, D.; Manno, N.; Demarchis, M.; Paoletti, M.G. Current views on fungal chitin/chitosan, human chitinases, food preservation, glucans, pectins and inulin: A tribute to Henri Braconnot, precursor of the carbohydrate polymers science, on the chitin bicentennial. Carbohydr. Polym. 2012, 87, 995-1012. [CrossRef]

196. Yuan, X.; Zheng, J.; Jiao, S.; Cheng, G.; Feng, C.; Du, Y.; Liu, H. A review on the preparation of chitosan oligosaccharides and application to human health, animal husbandry and agricultural production. Carbohydr. Polym. 2019, 220, 60-70. [CrossRef]

197. Grundemann, C.; Reinhardt, J.K.; Lindequist, U. European medicinal mushrooms: Do they have potential for modern medicine? An update. Phytomedicine 2020, 66, 153131. [CrossRef] [PubMed]

198. Wanmuang, F.; Leopairut, J.; Kositchaiwat, C.; Wananukul, W.; Bunyaratvej, S. Fatal fulminant hepatitis associated with Ganoderma lucidum (Lingzhi) mushroom powder. J. Med. Assoc. Thail. 2007, 90, 179-181.

199. Hisamochi, A.; Kage, M.; Arinaga, T.; Ide, T.; Miyajima, I.; Ogata, K.; Kuwahara, R.; Koga, Y.; Kumashiro, R.; Sata, M. Drug-induced liver injury associated with Agaricus blazei Murill which is very similar to autoimmune hepatitis. Clin. J. Gastroenterol. 2013, 6, 139-144. [CrossRef]

Publisher's Note: MDPI stays neutral with regard to jurisdictional claims in published maps and institutional affiliations.

(C) 2020 by the authors. Licensee MDPI, Basel, Switzerland. This article is an open access article distributed under the terms and conditions of the Creative Commons Attribution (CC BY) license (http://creativecommons.org/licenses/by/4.0/). 